\title{
Club Goods and Group Identity: Evidence from Islamic Resurgence during the Indonesian Financial Crisis
}

\author{
Daniel L. Chen
}

University of Chicago

\begin{abstract}
This paper tests a model in which group identity in the form of religious intensity functions as ex post insurance. I exploit relative price shocks induced by the Indonesian financial crisis to demonstrate a causal relationship between economic distress and religious intensity (Koran study and Islamic school attendance) that is weaker for other forms of group identity. Consistent with ex post insurance, credit availability reduces the effect of economic distress on religious intensity, religious intensity alleviates credit constraints, and religious institutions smooth consumption shocks across households and within households, particularly for those who were less religious before the crisis.
\end{abstract}

\section{Introduction}

Despite an explosion of policy interest in association with recent events, religious intensity appears poorly understood. What causes religious

I am extremely grateful to my principal advisor, Esther Duflo, for her guidance and intellectual generosity. I would also like to thank Joshua Angrist, David Autor, Abhijit Banerjee, Eli Berman, Ivan Fernandez-Val, Chris Hansen, Seema Jayachandran, Ben Olken, Vijayendra Rao, Zaki Wahhaj, Motohiro Yogo, and especially Jeremy Tobacman, the editor Canice Prendergast, and anonymous referees for comments. Maulina Cahyaningrum, Prima Fortunadewi, and Julius Kusuma provided outstanding translation assistance. Work on this project was conducted while I received financial support from the National Science Foundation Graduate Research Fellowship, MacArthur Foundation, Social Science Research Council, Massachusetts Institute of Technology Schultz Fund, National Institute of Child Health and Human Development, Russell Sage Foundation (which made possible my conducting interviews in Indonesia), John M. Olin Foundation, the Institute for Humane Studies, and the Petrie-Flom Center at Harvard Law School. All mistakes are my own.

[ Journal of Political Economy, 2010, vol. 118, no. 2]

(C) 2010 by The University of Chicago. All rights reserved. 0022-3808/2010/11802-0004\$10.00 
intensity? Does economic distress stimulate religious intensity? Is it economics or distress that stimulates religious intensity? Does religious intensity function as social insurance, distinctive from other insurance mechanisms in that religious groups help people who experience negative shocks after the fact whereas other insurance mechanisms require participation before the fact? How would such an ex post insurance mechanism be self-sustaining, and how does it compare with other insurance mechanisms during crises? These are some of the questions that this paper seeks to address. Social scientists have long speculated on the connection between economic forces and religious intensity; answers to these questions may suggest appropriate policies to address ideological extremism.

This paper uses the Indonesian financial crisis to estimate the causal impact of economic distress on communal Koran study (pengajian) and Islamic school attendance (for children) and to provide evidence consistent with a model of religious intensity functioning as social insurance. Between 1997 and 1998, Indonesia's rupiah fell dramatically from 2,400 to the U.S. dollar to 16,000 to the U.S. dollar, and the consumer price index (CPI) for food increased from 100 to 261. My empirical strategy exploits the fact that relative price shocks induced by the crisis favored growers of staples, namely rice, and hurt sticky wage earners, particularly government employees whose salaries are set by federal law. Because precrisis wetland hectares and government occupation are unlikely to be correlated with changes in religious intensity other than through economic distress, the interaction of the crisis and wetland hectares and the interaction of the crisis and government occupation create exogenous variation in economic distress that can be used to estimate the causal impact of economic distress on religious intensity. Dryland hectares and service occupation serve as "placebo instruments" to test whether unobservables common with both wetland and dryland hectares or with both government and service occupations are correlated with changes in religious intensity.

In the following sections, I present an analysis of data from the Hundred Villages Survey, a panel of 8,140 households followed by the Indonesian Central Statistics Office before and after the crisis and in which religious intensity is measured using Koran study and the sending of one's children to Islamic school. Section II discusses a theory of religious intensity functioning as ex post social insurance. Section III establishes that wetland hectares and government occupation are indeed related to economic distress during the crisis. The price of rice increased by up to 280 percent, whereas in comparison, prices of nonstaples increased by less or even fell during the crisis (Levinsohn, Berry, and Friedman 2003). Therefore, the more wetland a household owns, the smaller the decrease in nonfood expenditure. In contrast, real wages 
fell on the order of 40 percent (Smith et al. 2002), so households headed by a government employee, whose salaries tend to be inflexible in the short run (Knowles, Pernia, and Racelis 1999), report larger decreases in nonfood expenditure.

The variety of evidence presented in Section III establishes that the financial crisis differentially affected wetland owners and government employees during the crisis. In Section IV, I consider whether households suffering greater economic distress increase religious intensity. Two-stage least squares estimates using this variation suggest that households that suffer more economic distress significantly increase religious intensity whereas those that suffer less economic distress significantly decrease religious intensity relative to other households. The estimates indicate that households that suffer a $\$ 1.00$ decline in monthly nonfood per capita expenditures are roughly 2 percentage points more likely to increase Koran study. The average household suffered a $\$ 4.70$ decline in monthly nonfood per capita expenditures out of a precrisis average of $\$ 7.34$.

I also look at the effect of economic distress on the number of children that households send to Islamic schools. In spite of the fact that Islamic schools in my sample are substantially more expensive than non-Islamic schools (and have lower returns to education [Berman and Stepanyan 2003]), Islamic school attendance of affected households increases relative to the attendance of less affected households. These results suggest that religious intensity increases with economic distress and, perhaps as a consequence, intergenerational religious intensity as well.

I then explore why economic distress stimulates religious intensity. Family deaths, in particular, deaths of infants, do not stimulate religious intensity. Moreover, economic distress does not stimulate participation in other social activities (including rotating savings groups, an alternative insurance mechanism). These results indicate that something particular about economic distress, not distress more generally, stimulates religious intensity and that religious intensity provides something distinctive that other social activities or insurance mechanisms do not provide, such as the provision of ex post insurance. To shed further light on whether Koran study is merely a leisure activity and households have more leisure, I investigate the effect of economic distress on labor supply. Households suffering more economic distress work slightly more hours per week. These results are inconsistent with opportunity cost of time models of religion that do not account for social insurance since falling wages do not increase participation in other social activities and households have less time for religious activity.

In Section V, I turn to the evidence for religious intensity as social insurance. Religious intensity during the peak of the crisis alleviates the need for alms or credit in order to meet basic daily needs: households 
that increase participation in Koran study during the crisis see a 49 percent reduction in the likelihood of needing alms or credit 4 months later, whereas households that decrease participation see a 21 percent reduction in the likelihood of needing alms or credit 4 months later; those that did not participate are only 6 percent less likely to need alms or credit 4 months later. Second, I find that religious institutions facilitate consumption smoothing among villagers by reducing the spread of consumption shocks among villagers during the crisis. This finding is identified by interacting the precrisis number of worship buildings with the Gini coefficient of wetland ownership as an instrument for the impact of the crisis on the standard deviation of consumption shocks (since wetland ownership cushions households, the Gini coefficient of wetland instruments for the inequality of cushions). Third, religious institutions also reduce the effect of income shocks on consumption shocks: religious institutions mitigate the relationship between the instruments for economic distress and economic distress. However, religious institutions cushion consumption shocks more for households that were previously less religious before the crisis as measured by whether any household members attended Islamic school or the haj.

Importantly, the effect of economic distress on religious intensity essentially disappears in places where credit is available in the form of banks, microfinance institutions, or Bank Rakyat Indonesia (BRI) loan products. The role of religion as a provider of insurance is broadly consistent with club goods theory (Buchanan 1965; Iannaccone 1992; Berman 2000; Scotchmer 2002), which posits the existence of local public goods, such as mutual insurance and in-group altruism, that are excluded for nongroup members (Chen and Li 2009).

Religious intensity provides a particularly apt context to study group identity since it is likely more of a choice than ethnicity. Several authors have found significantly negative impacts of ethnic-religious conflicts on economic outcomes (e.g., Alesina, Baqir, and Easterly 1999; Abadie and Gardeazabal 2003). The opposite direction of causality has also begun to attract attention and spark debate (e.g., Wolfensohn [2003] vs. Krueger and Maleckova [2003] on whether economic conditions cause terrorism). This paper also contributes to the literature on the determinants of religion, which has received a recent boost with the work of Gruber (2004, 2005), Barro and McCleary (2006), and Glaeser and Sacerdote (2008), and the literature on consumption smoothing (households can smooth through borrowing and lending, through storage, through transfers in family networks, or through religious participation) and insurance (Townsend 1994). Together with the finding that religious intensity is more strongly linked to social violence in regions that are more economically distressed (Chen 2007), these results suggest that to the extent that governments, international organizations, 
and nongovernmental organizations are concerned about ideological extremism, increasing the provision of social insurance may mitigate fundamentalist tendencies.

\section{Religion and Economics}

\section{A. Indonesia Background}

Of Indonesia's population of 230 million, 87 percent is Muslim, making it the country with the largest (Sunni) Muslim population in the world. The primary measure of religious intensity being studied is pengajian, which specifically refers to communal Koran study. In my sample, 61 percent of households report participating in pengajian in August 1998, and this increases to 71 percent in August 1999. The second measure of religious intensity being studied is the sending of one's children to Islamic school. In a nationwide survey, 18 percent of Muslim households with school-age children sent their children to Islamic school in 1997 (Indonesian Family Life Survey [IFLS]), which increases to 30 percent in 1999 (Wagner 1999).

\section{Pengajian}

In most Islamic denominations, the Koran is kept in its strictest form, meaning that it cannot be translated. During pengajian, a group gathers to read the Koran together in Arabic, discussing both the translation and the meaning. A leader is responsible for translating and applying the Koran to the real world in a lecture format. Lessons on how to live and perspectives on contemporary events are common material for discussion. Pengajian can become politicized, though it usually focuses on general religious and social doctrine. Geertz (1960) observes one pengajian meeting in which a speaker exhorts on the importance of attending and organizing, ridiculing those who only sit and pray, thinking about the next world and doing nothing else: "The Prophet not only prayed but prayed and acted" (169). In Geertz's view, pengajian tends to be a kind of rally, where speakers exhort listeners in the most general terms to rouse up and do something. More recent ethnographic observations of a women's pengajian group suggest a modernizing trend (Kipp 1993). A leader begins the women's meetings with 40 minutes of responsive reading, in which she gives a sentence and then the group responds, all in Arabic. The leader reads from Arabic, but most follow her in a book of Latin-script transcriptions. Some simply work from memory. The teacher then talks for 30-40 minutes, sometimes expounding on a verse from the Koran, sometimes giving moral instruction. 
Instruction can be directive and social sanctions against nongroup members or nonparticipants implicit.

Individuals can attend multiple pengajians. Each mosque has multiple pengajians. There are local and regional pengajians. They can meet more often than once per week. According to personal interviews, individuals attend to avoid social sanctions, such as shaming, from their neighborhood. The typical number of participants depends on village size and the number of Muslims and imams. Men and women may attend pengajian together, although there is typically a separation between them. Pengajians for children and teenagers usually number around 25-50 people. Adult pengajians can have 50-80 villagers (Kim 2007). A separate pengajian exists for children to teach them how to read the Koran. Not every Muslim knows how to read Arabic, nor does every participant need to be able to read Arabic since participants will be taught the language if necessary.

Pengajian participation is strongly correlated with all measures of religious intensity available in my data. The correlation is strong and positive both unconditionally and conditionally on household characteristics and village fixed effects. Pengajian participation in August 1998 is correlated with the number of children attending Islamic school at 5 percent significance, with the number of adults who attended Islamic school as children at 1 percent significance, with owning a Koran at 1 percent significance, and with worshipping in December 1998 at 1 percent significance. Moreover, these religious intensity measures are strongly correlated with communal violence in the Database on Social Violence in Indonesia 1990-2001 (Chen 2007).

\section{Islamic School}

Islamic schools come in a wide variety, but one commonality is their being sought by parents who wish their children to become good Muslims. Formal public education in Indonesia is provided by two main national networks: secular and religious. The three levels of public madrasah studied in my sample are called ibtidaiyah, tsanawiyah, and aliyah. These are Islamic madrasah that educate students at the elementary, junior secondary, and senior secondary levels, respectively, and are statecertified as meeting the education requirements for degree-granting institutions. The proportions of secular and religious subjects in these madrasah vary, but the Ministry of Religious Affairs sets a standard of 70 percent for secular and 30 percent for religious subjects. Returns to schooling at Islamic schools (pesantren or madrasah) are lower than at non-Islamic schools (Berman and Stepanyan 2003).

Madrasah and pesantren are different. Madrasah are considered a complement to, not a substitute for, pesantren because of the perception 
that madrasah are inferior to pesantren in the transmission of religious knowledge, so attendance in madrasah and pesantren may be correlated. Parents with additional means and who are more concerned with bettering their children's religious education prefer to send them to pesantren (Muhaimin 2006). Under the direction of a Muslim scholar, pesantren are attended by young people who are taught a detailed understanding of the Koran, the Arabic language, the Sharia, and Muslim traditions and history. Students can enter and leave any time of the year, and the studies are not organized as a progression of courses leading to graduation (Jay 1969; Library of Congress 1992). Geertz (1960) writes of one pesantren in which young men aged 6-25 spend part of every day chanting the Koran and part of it working in the leader's fields. Attendance is not mandatory, and there is no fixed schedule as long as a young man earns his keep and creates no behavior problems. Private education is typically more organized and more expensive and sometimes for the elite, though traditional pesantren may be free, sponsored by organizations or wealthy individuals (Nelles 2003). In my sample, parents report paying substantially larger fees at Islamic schools than at non-Islamic schools.

Sending one's children to Islamic school is correlated with stronger forms of religious belief. Bearing in mind that answers to direct questions on attitude or belief suffer from cognitive bias with unknown error distribution (Greenwald and Banaji 1995; Bertrand and Mullainathan 2001), I correlate Islamic school attendance with indirect measures of beliefs in the IFLS. Whether a household has ever sent a child to Islamic school is correlated with religious opposition to contraception at 5 percent significance; the fraction of households with religious opposition to contraception is 0.10 . Religious opposition to contraception is a dummy for answering, without prompting, religious reasons for "Why do you not use contraception?" Whether a household has ever sent a child to Islamic school is correlated with religious fatalism in the desired number of sons at 0.051 with 10 percent significance; the fraction of households with religious fatalism in the desired number of sons is 0.26. Religious fatalism in the desired number of sons is a dummy for answering "It is up to God" in response to "What is your ideal number of sons?" This answer is also not prompted by the survey. In sum, sending one's children to Islamic school is strongly correlated with observable measures of beliefs arguably hewing closer to a literal interpretation of a religious text.

\section{B. Model Description}

A growing body of empirical work by economists documents a semiformal social insurance existing on the basis of religious obligation (Gruber 
and Hungerman 2005; Hungerman 2005; Dehejia, DeLeire, and Luttmer 2007). Berman (2000) notes that the degree of mutual insurance (in the Ultra-Orthodox sect in Israel) probably exceeds that of traditional Indian villages studied by Townsend (1994). Berman writes, citing Landau (1993), that no sick members are without visitors and that if members donate time and money, they can receive free services for burial, assistance for new babies or the elderly in their household, and interest-free loans from hundreds to thousands of dollars. Social insurance, however, is not limited to those who participate ex ante. Personal interviews conducted in Indonesia suggest that religious organizations help individuals after they experience negative income shocks. One Islamic school reported increasing attendance during the crisis by offering scholarships to students who could no longer afford public school fees. Moreover, one pengajian group facilitated ex post insurance by rapidly increasing membership and matching individuals seeking employment and employers seeking workers through public announcements.

In an earlier version of the paper (Chen 2009), I illustrate in a simple model how religion can provide ex post social insurance. I model group identity in the form of religious intensity as representing the degree of social insurance in which people participate. Recent experimental evidence documents that induced group identity increases the degree of altruism toward in-group members (Chen and Li 2009). But what sustains groups that immediately help those who join after receiving a negative shock? I posit that religious groups are able to provide ex post insurance (insurance after some but not all information is revealed) and break even in their budget because social sanctions overcome the individual rationality constraints that would otherwise prevent ex post insurance groups from forming. Economists have noted that social pressure and individual guilt can work as enforcement mechanisms for social insurance (Fafchamps 2004). Guilt is nurtured through religious and family education, but more formal enforcement mechanisms are implemented by organized groups that fund social insurance programs (Ellsworth 1989). A strong form of social sanction toward those who belong to other religious organizations or are less religiously intense, provided in the doctrine of many religions, including those in Indonesia (Muhaimin 2006), facilitates religion's function as ex post insurance by encouraging people who receive positive shocks to participate. Mutual insurance groups without such strong social sanctions, such as rotating savings groups, will be less stable during periods of extraordinary volatility. 


\section{Qualitative Evidence}

The role of charity and insurance in Islam in Indonesia has been noted in a survey of the religious studies literature (Marty and Appleby 199195). Religious leaders organize charities, administer mosque funds, seed Koran study groups, and run Islamic boarding schools (Hadiwinata 2003). Religious leaders also frequently act as patrons for villagers seeking employment or credit, accentuating their role as social insurance providers (Schiller 1996). Over 2,600 Islamic boarding schools on Java have both economic and social programs aiding community development (Moran 1996), and Islamic charities have been tied to terrorist groups, such as al-Qaeda (Burr and Collins 2006).

Pengajian, while not the sole forum through which social insurance occurs in Indonesian villages, appears to act as the nexus for the religious provision of social insurance. Donations to the mosque typically occur during pengajian (even though pengajians can be held away from the mosque, in any public or private space). Donations can be used to build new mosques, maintain current mosques, pay salaries, or help people in need. The role of monetary contributions has been noted by ethnographers (Kipp 1993), the World Bank, and surveys. The World Bank describes pengajian as follows: "Activities include reading and discussions from religious texts and communal prayers, together with savings and credit activities and sharing of concerns. Those who happen to have met with misfortunes can share their problems at the Pengajian and hope to find caring listeners and may even receive small amounts of material assistance" (Mukherjee 1999, 94). In a survey on how households cope with poverty, pengajian is the only community institution that received a high rating by all groups, rural and urban, men and women. According to Mukherjee's report, it was ranked higher in importance and effectiveness than arisan (savings and loan cooperation).

Pengajian donations accumulate to a sizable amount, a large fraction of which is devoted to charity. A recent ethnography estimates that half a million rupiah was collected between 1987 and 1988 (Kim 2007). In my own field work, I collected balance sheet data showing donations, attendance, and social welfare spending by one religious group in Banjarnegara, one of the villages in the Hundred Villages Survey. Charitable expenditures amount to 35 percent of total donations. For comparison, in the United States, up to 20-25 percent of church expenditures are for charitable purposes, exceeding \$24 billion in philanthropic services annually (Biddle 1992; Gruber and Hungerman 2005). 


\section{Design of the Study}

\section{A. Data}

The empirical analysis draws from the Hundred Villages Survey, collected by the Indonesian Central Statistics Office. The panel data set follows 8,140 households from May 1997 to August 1999, beginning before the crisis and continuing in four waves after the crisis (fig. 1). Pengajian is measured using the response to "In the past 3 months, has your household increased, decreased, stayed the same, or not participated in the study of Koran (pengajian)?” This question is asked right after the peak of the crisis in August 1998 and is coded as $+1 / 0 /-1$. Nonparticipation is coded along with staying the same as 0 . The main results do not change when nonparticipation is coded as -0.5 or when it is excluded. In some specifications, I also code separately increase versus stay the same or decrease and decrease versus stay the same or increase. All households are able to increase participation since mosques have multiple pengajians, villages have multiple mosques, pengajians can meet multiple times per week, and individuals can attend local as well as regional pengajians.

The measure of economic distress I focus on is change in monthly per capita nonfood consumption expenditures instead of food consumption expenditures because the data do not distinguish consumption expenditures for home-grown food; the data provide only a category for food expenditures more generally. Change in total (nonfood and food) per capita consumption expenditures is a poorer measure of distress because landowners able to grow their own food do not need to pay market prices for food and may substitute toward consuming privately grown agricultural products. Wetland hectares (and dryland hectares) are in fact correlated, conditionally and unconditionally, with larger than average decreases in per capita food expenditures even though they are correlated, conditionally and unconditionally, with smaller than average decreases in per capita nonfood expenditures. Government workers have larger decreases in both per capita nonfood and food expenditures.

Since consumption is the only available economic variable (income is not available for all households in the data set), I use consumption as a proxy for economic welfare. I instrument for consumption using two measures of income shock: the amount of wetland holding and government occupation. Pengajian is recorded only after the crisis, so I cannot examine whether precrisis pengajian participation mitigates the effect of income shocks on consumption shocks as a Townsend (1994) insurance test, but I do examine whether other religious institutions measured before the crisis, such as religious worship buildings 


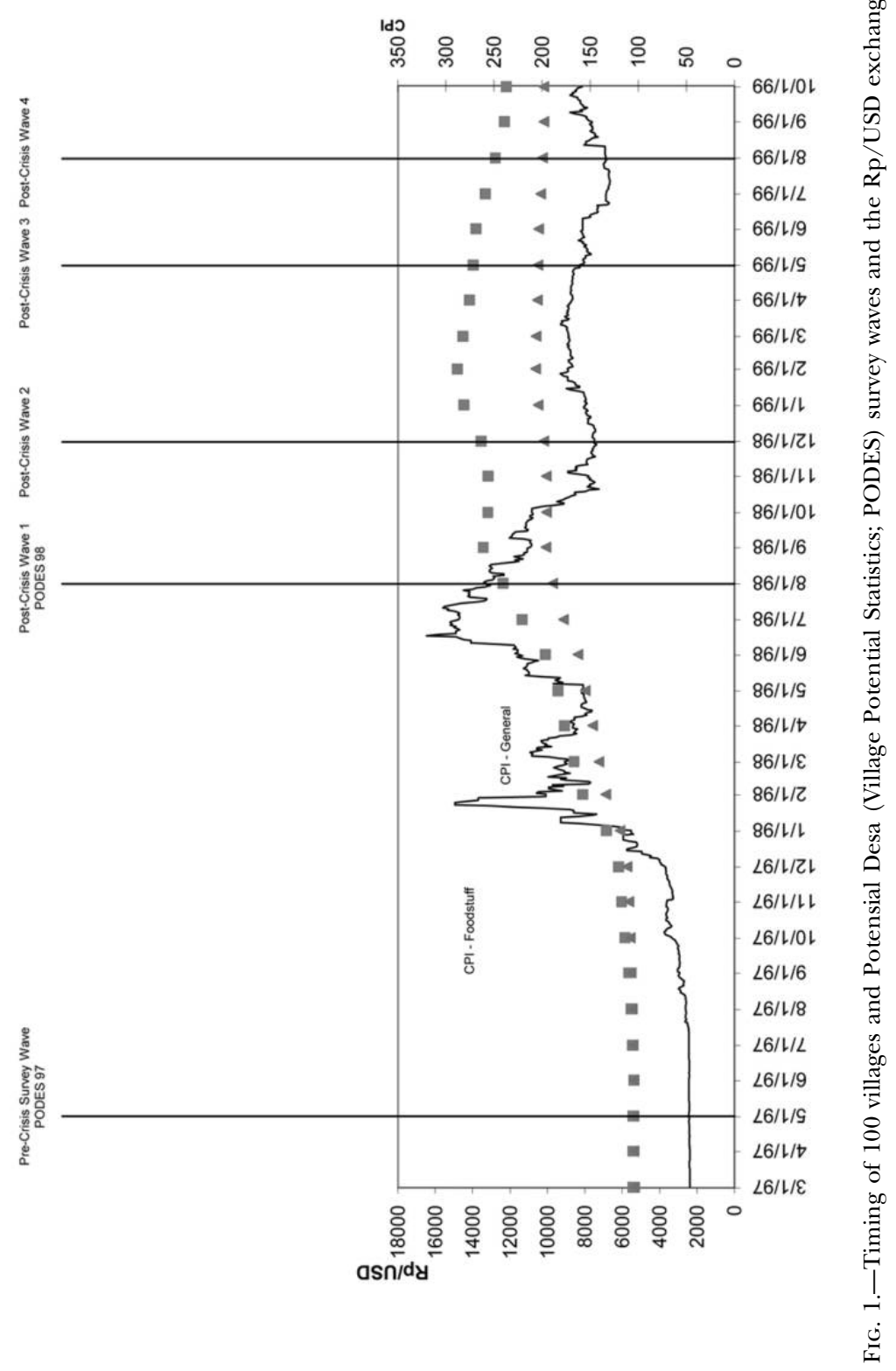


and whether a household was more religiously committed with members attending Islamic school or the haj, affect consumption smoothing.

The measure for change in religious intensity comes from May 1998 to August 1998 since the pengajian question refers to the past 3 months, whereas the measure for income shock comes from differencing expenditures in May 1997 and August 1998 (see fig. 1). However, as the time series in figure 1 suggests, half of the sharp increase in rupiah per U.S. dollar (Rp/USD) occurs in the 3 months before August 1998. The CPI index for foodstuffs also sharply increases relative to the general CPI index during this time period. Therefore, the manner in which wetland owners and government workers are disproportionately affected by the relative price shocks should still apply for the 3 months before August 1998. The results are qualitatively the same using a CPI index or the Rp/USD exchange rate to normalize to dollars. The data set and remaining variable construction are described in greater detail in Appendix A.

\section{B. Identification Strategy and Specifications}

The correlation between economic variables and religious intensity is generally difficult to interpret since the causality may run in both directions and the relationship may reflect omitted variables. I therefore use the financial crisis to identify a discontinuous change in economic conditions.

Consider the following linear specification for latent religiosity:

$$
\begin{gathered}
Q_{i j t}^{*}=\beta E_{i j t}+\alpha_{0 t}+\alpha_{1 t}^{\prime} \mathbf{X}_{i j}+\delta_{j t}+u_{i}+\varepsilon_{i j t} \\
\text { for } t=1,2, i=1, \ldots, N \text {, and } j=1, \ldots, J
\end{gathered}
$$

where $Q_{i j t}^{*}$ represents religious intensity for individual $i$ in village $j$ at time $t, E_{i j t}$ represents monthly per capita nonfood expenditures, $\mathbf{X}_{i j}$ represents a set of precrisis control variables (household head characteristics: age, education, gender, ever married, literate, follows media [television or radio]; and household characteristics: size, modernity [index of owning a stove, radio, television, refrigerator, satellite dish, motorbike, and car], farming dummy, service dummy, hectares of dryland owned, and precrisis monthly per capita nonfood expenditures), ${ }^{1} \delta_{j t}$ represents village time fixed effects, and $u_{i}$ represents household fixed effects. The subscript $t$ on $\alpha_{1 t}$ allows the effect of precrisis control variables $\mathbf{X}_{i j}$ to vary over time.

\footnotetext{
${ }^{1}$ Construction of these variables is described in App. A.
} 
Taking first differences (implicit individual fixed effects) results in

$$
\begin{gathered}
\Delta Q_{i j}^{*}=\beta \Delta E_{i j}+\left(\alpha_{02}-\alpha_{01}\right)+\left(\alpha_{12}-\alpha_{11}\right)^{\prime} \mathbf{X}_{i j}+\gamma_{j}+\omega_{i j} \\
\text { for } i=1, \ldots, N \text { and } j=1, \ldots, J,
\end{gathered}
$$

where $\Delta Q_{i j}^{*}$ represents changes in religious intensity for individual $i$ in village $j, \Delta E_{i j}$ represents changes in monthly per capita nonfood expenditures, $\gamma_{j}=\delta_{j 2}-\delta_{j 1}$ represents village fixed effects, and $\omega_{i j}=$ $\varepsilon_{i j 2}-\varepsilon_{i j 1}$.

In practice, $\Delta Q_{i j}^{*}$ is unobserved. Instead, I observe $\Delta Q_{i j}$, which denotes increase, decrease, or no change in Koran study. In particular, I first estimate the linear probability specification

$$
\Delta Q_{i j}=\beta \Delta E_{i j}+c+\alpha^{\prime} \mathbf{X}_{i j}+\gamma_{j}+\varepsilon_{i j},
$$

where $\Delta Q_{i j}$ represents changes in Koran study for individual $i$ in village $j, \gamma_{j}$ represents village fixed effects, and $c$ is a constant. Because $\Delta Q_{i j}$ has the following ordered structure,

$$
\Delta Q_{i j}= \begin{cases}-1 & \text { if } \Delta Q_{i j}^{*} \leq \mu_{1} \\ 0 & \text { if } \mu_{1} \leq \Delta Q_{i j}^{*} \leq \mu_{2} \\ 1 & \text { if } \Delta Q_{i j}^{*} \geq \mu_{2},\end{cases}
$$

I then estimate the following ordered probit specification to test whether economic distress stimulates religious intensity:

$$
\begin{aligned}
\operatorname{Pr}\left(\Delta Q_{i j}=-1 \mid \mathbf{I}_{i j}\right)= & F_{\omega_{i j}}\left(\mu_{1}-\beta \Delta E_{i j}-\left(\alpha_{02}-\alpha_{01}\right)\right. \\
& \left.-\left(\alpha_{12}-\alpha_{11}\right)^{\prime} \mathbf{X}_{i j}-\gamma_{j} \mid \mathbf{I}_{i j}\right), \\
\operatorname{Pr}\left(\Delta Q_{i j}=0 \mid \mathbf{I}_{i j}\right)= & F_{\omega_{i j}}\left(\mu_{2}-\beta \Delta E_{i j}-\left(\alpha_{02}-\alpha_{01}\right)\right. \\
& \left.-\left(\alpha_{12}-\alpha_{11}\right)^{\prime} \mathbf{X}_{i j}-\gamma_{j} \mid \mathbf{I}_{i j}\right)-F_{\omega_{i j}}\left(\mu_{1}-\beta \Delta E_{i j}\right. \\
& \left.-\left(\alpha_{02}-\alpha_{01}\right)-\left(\alpha_{12}-\alpha_{11}\right)^{\prime} \mathbf{X}_{i j}-\gamma_{j} \mid \mathbf{I}_{i j}\right), \\
\operatorname{Pr}\left(\Delta Q_{i j}=1 \mid \mathbf{I}_{i j}\right)= & 1-F_{\omega_{i j}}\left(\mu_{2}-\beta \Delta E_{i j}-\left(\alpha_{02}-\alpha_{01}\right)\right. \\
& \left.-\left(\alpha_{12}-\alpha_{11}\right)^{\prime} \mathbf{X}_{i j}-\gamma_{j} \mid \mathbf{I}_{i j}\right),
\end{aligned}
$$

where $\mathbf{I}_{i j}=\left(1, \mathbf{X}_{i j}, \gamma_{j}\right)$ and $\left.F_{\omega_{i j}} \cdot \cdot \mid \mathbf{I}_{i j t}\right)$ is normal. Equation (2) is the linear approximation of the ordered probit specification. I estimate linear probability, ordered probit, and probit specifications (when comparing only increase vs. stay the same or decrease and decrease vs. stay the same or increase). The incidental parameters problem is mitigated because I have 100 villages and 8,140 households, roughly an $80: 1$ ratio.

Even with individual fixed effects, a difference-in-differences framework correlating economic distress and changes in religious intensity 
may still lead to biased estimates because increases in religious intensity will, in turn, mute the economic distress that stimulated it. Moreover, omitted variables such as a propensity for taking fewer precautions may be correlated with suffering greater economic distress and changes in religious intensity.

To identify the causal impact of economic distress, I exploit the fact that during a period of rapid inflation, demand for nonstaples tends to fall more than demand for staples, so relative prices favor staple growers. The price of rice increased by up to 280 percent, whereas in comparison, prices of nonstaples increased by less or even depreciated during the crisis (Levinsohn et al. 2003). The more rice a household grows, the more cushioned it would be from the crisis. Therefore, the amount of wetland a household owns before the crisis should be expected to cushion it from economic distress during the crisis.

In addition, rapid inflation tends to disproportionately affect workers with sticky wages. In particular, government workers, whose wages are set by federal law, are likely to suffer greater economic distress. Most government workers in rural areas work in education or health, and their basic salary is fixed by national law on the basis of their rank and experience. Since government workers also own land (the average government household owns 0.56 hectare of dryland and 0.15 hectare of wetland whereas the average nongovernment household owns 0.73 hectare of dryland and 0.17 hectare of wetland), the two instruments employ complementary variation to estimate the causal effect of economic distress on religious intensity. The differential impact of the financial crisis based on government occupation and wetland ownership has already been documented by earlier studies of the Indonesian financial crisis (e.g., Frankenberg, Thomas, and Beegle 1999; Knowles et al. 1999; Levinsohn et al. 2003).

The first-stage regression is

$$
\Delta E_{i j}=\pi_{0}+\pi_{1}^{\prime} \mathbf{Z}_{i j}+\pi_{2}^{\prime} \mathbf{X}_{i j}+p_{j}+\eta_{i j}
$$

where $\mathbf{Z}_{i j}$ represents the instruments, precrisis hectares of wetland owned, and a precrisis government occupation dummy for individual $i$ in village $j$. The corresponding reduced-form regression is

$$
\Delta Q_{i j}=\beta^{\prime} \mathbf{Z}_{i j}+c+\alpha^{\prime} \mathbf{X}_{i j}+\gamma_{j}+\varepsilon_{i j} .
$$

The identification assumption is $E\left(\varepsilon_{i j} \mathbf{Z}_{i j}\right)=0$. The most important potential threat to this assumption is that the instruments, wetland hectares and government occupation, may be correlated with omitted factors that affect changes in religious intensity. To the extent that dryland owners share unobservable characteristics with wetland owners and service workers share unobservable characteristics with government workers, examining the correlation between these "placebo" instruments and 
changes in religious intensity serves as one check of the identification assumption. Second, wetland hectares and government occupation may be associated with differential trends in religious intensity and economic change that coincide with the financial crisis. To explore whether the differential changes in religious intensity reflect differential trends, I examine whether 1 year after the crisis, between two periods without a crisis, the instruments are associated with either economic distress or changes in religious intensity.

The basic idea behind the identification strategy can be illustrated in a differences-in-differences framework. In table 1, I present summary statistics by group that outline the identification strategy. The results are imprecise because only a small part of the available information is used. Columns 1 and 2 show the mean monthly per capita nonfood expenditure before and after the crisis for different categories of wetland hectares (greater than or less than 0.3 hectare) and whether or not the household head works in government. These estimates are unconditional correlations and do not control for possible differentiating characteristics of household heads who work in government or of households that own more wetland. For controls, see specification 1 and the estimates in the subsequent sections. Columns 3-5 show for each category of wetland and government occupation the means of changes in monthly per capita nonfood expenditure, pengajian participation, and participation in nonreligious social activities. Two important features of the data can be observed. First, households owning more wetlandwhich, on average, suffered less economic distress-tend to decrease pengajian relative to other households. Second, households in government occupations-which, on average, suffered greater economic distress-tend to increase pengajian relative to other households. Column 5 shows that the same pattern is not true for nonreligious social activities. The Wald estimate (an imprecise instrumental variables estimator) of the impact of economic distress on religious intensity is the ratio of pengajian change and economic distress and can be obtained by dividing -0.022 by $1.4(-0.016)$ or 0.068 by $-4.8(-0.014)$.

\section{First Stage: Relative Price Shocks and Differential Impact of the Financial Crisis}

Table 2 documents the relationship between wetland hectares and per capita nonfood expenditure changes during the crisis using the specification in equation (3). On average, an additional hectare of wetland corresponds to a $\$ 1.13$ smaller decrease in per capita nonfood expenditures relative to other households (col. 5). Being in government corresponds to roughly a \$2.04 larger decrease in per capita nonfood expenditures relative to other households (col. 5). The relationship holds 


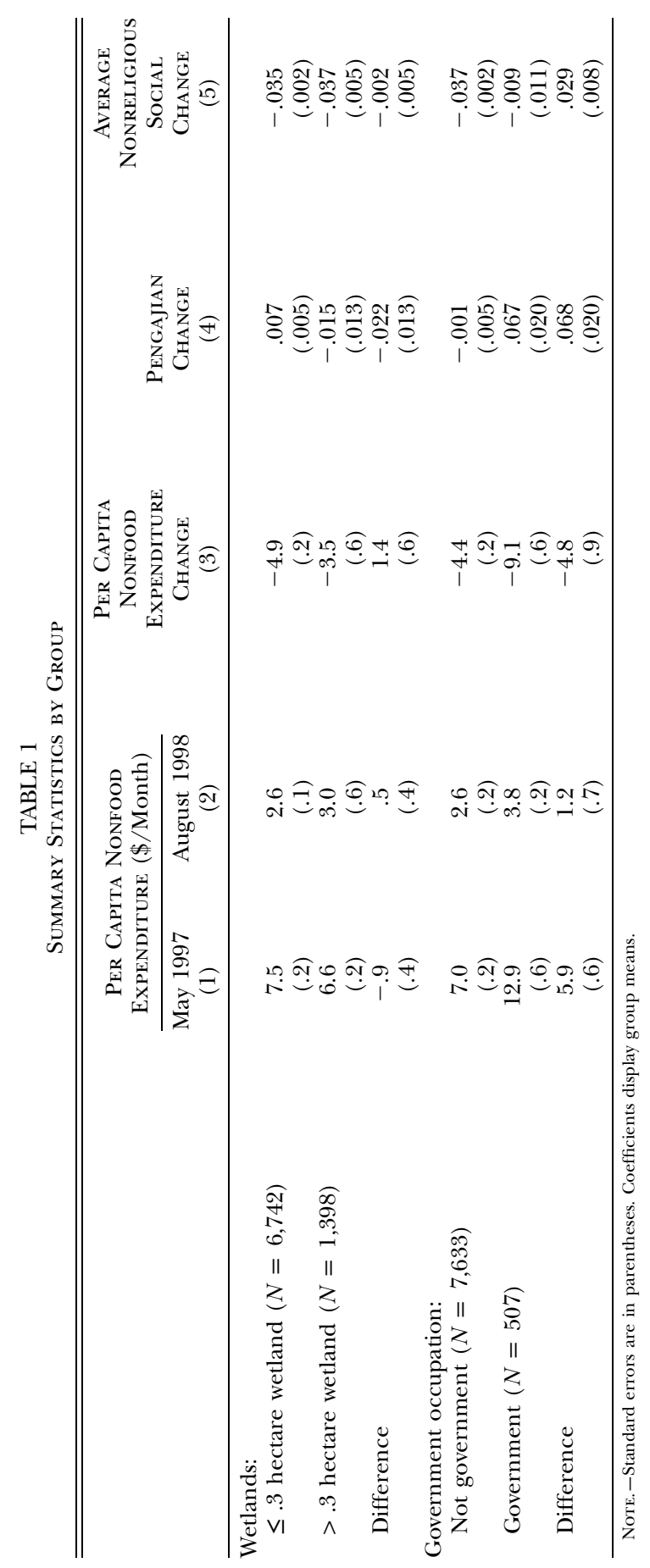




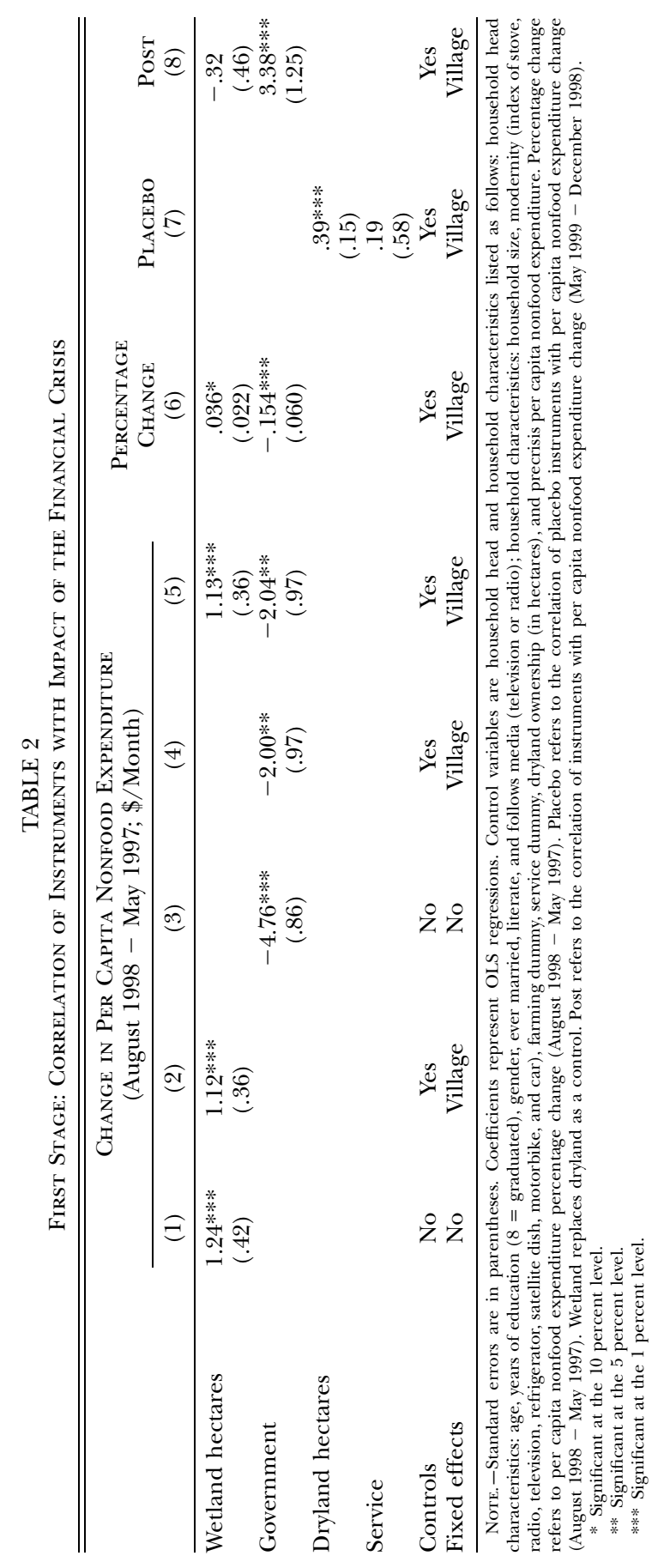


with and without controlling for household characteristics and village fixed effects (cols. 1-4). The F-statistic of joint significance of wetland hectares and government occupation is 7.16 in column 5 . These results corroborate earlier findings by Frankenberg et al. (1999) and Levinsohn et al. (2003), who find that those who were able to grow rice were less affected by the crisis as rice prices and spending on rice dramatically increased. The results also corroborate findings by Knowles et al. (1999), who find that government workers were more affected by the crisis since their salaries tended to be inflexible in the short run.

Column 6 displays similar results when examining percentage changes in per capita nonfood expenditures. For example, dividing the government expenditure change, $\$ 2.04$, by the baseline, $\$ 12.90$ (indicated in col. 1 of table 1 ), gives roughly a 15 percent decline, the same percentage decline indicated in column 6 of table 2. Changes in $\log$ expenditures, however, do not give a statistically significant first stage for wetland. Frankenberg et al. (1999) examine changes in log expenditures using the IFLS and find that those whose main activity is agriculture were relatively better off. It is possible that the poor, who often do not collect wages in developing countries, report more poorly measured and noisy expenditure numbers; this has been found to be the case in the United States (Meyer and Sullivan 2007) and so may be expected to plague developing countries more. This nonclassical measurement error may bias estimates using logs, which emphasize the poorer part of the distribution. One must remain agnostic about exactly which form of economic distress stimulates religious intensity. Without additional instruments for each channel of causality, it is not possible to isolate the potentially different effects of actual changes (sticker shock) versus percentage changes (relative changes) or per capita changes versus overall changes, and so forth.

\section{Estimating the Impact of Economic Distress on Religious Intensity}

\section{A. Reduced-Form Evidence}

Do people who experience larger negative shocks relative to others increase their religious intensity? To examine whether wetland owners are less likely to increase religious intensity and whether government workers are more likely to increase religious intensity, I estimate equation (4). Panel A in table 3 shows the main experiment. On average, a hectare of wetland is associated with a 2-percentage-point greater likelihood of decreasing pengajian whereas government occupation is associated with a 6-percentage-point greater likelihood of increasing pengajian (cols. 1 and 3), suggesting that economic distress stimulates 


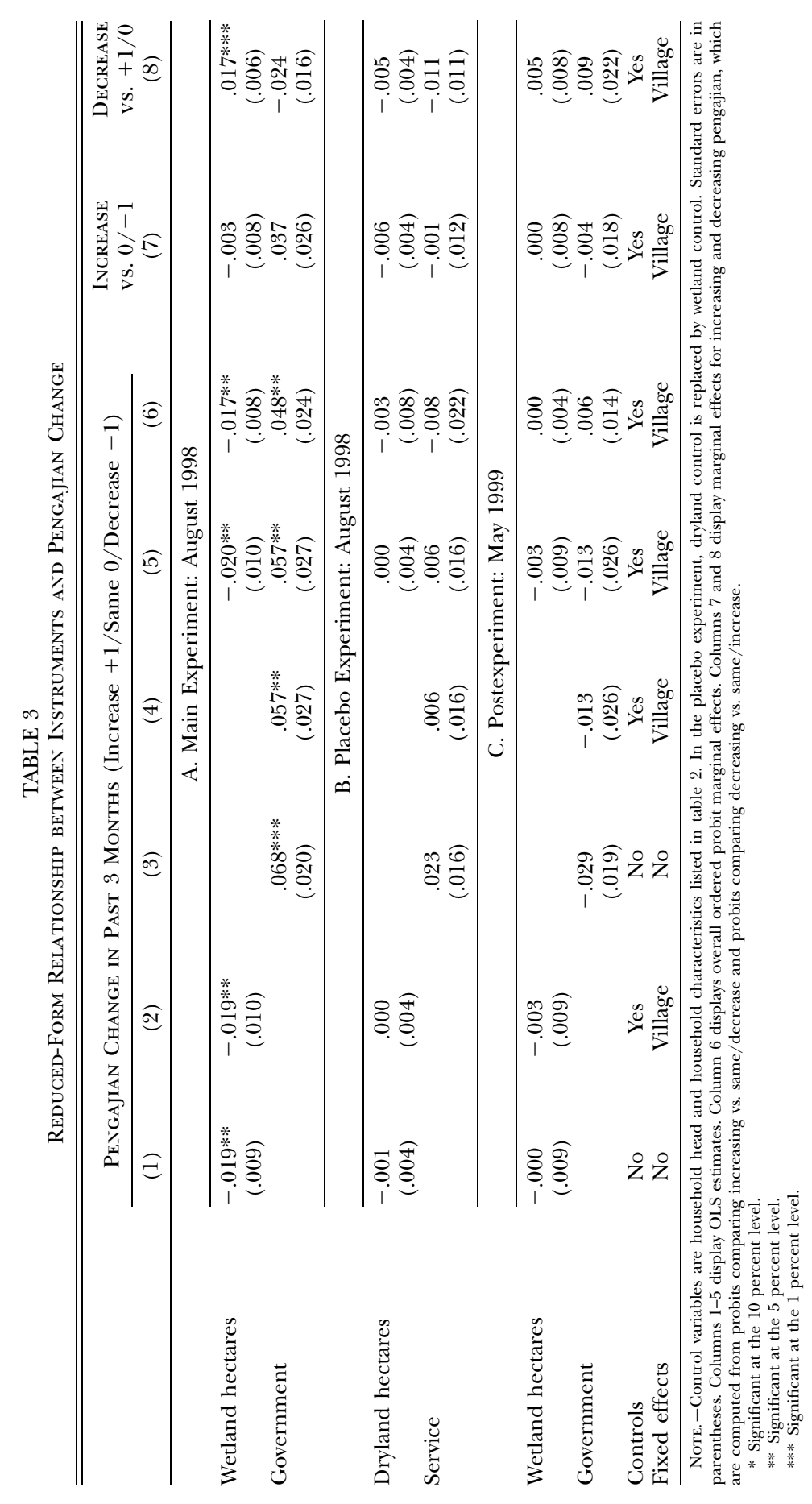


religious intensity. This relationship holds when I control for household characteristics and village fixed effects (cols. 2 and 4 ).

Column 5 displays the joint estimation and column 6 displays the overall ordered probit marginal effect. ${ }^{2}$ The estimates of marginal effects in column 6 are very similar to the ordinary least squares (OLS) estimates in column 5. I then compute the probit marginal effect for increasing $(+1$ vs. $0 /-1)$ in column 7 and the probit marginal effect for decreasing $(-1$ vs. $0 /+1)$ in column 8 . The differences between the marginal effects in column 7 and the marginal effects in column 8 are very similar to the OLS estimates in column 5 . Moreover, columns 7 and 8 reveal that those who realize a high income shock relative to others decrease their religious intensity during a crisis whereas those who realize a low income shock relative to others increase their religious intensity during a crisis.

\section{B. Placebo Experiment}

In examining the causal impact of economics on religion, it is reasonable to think that the financial crisis was neither an anticipation nor a consequence of religious fervor. However, several possibilities still threaten the identification assumption. The most important potential problem is that the instruments, wetland hectares and government occupation, may be correlated with omitted factors that drive changes in religious intensity. To test this possibility, I use dryland hectares and service occupation as "placebo instruments" for wetland hectares and government occupation. To the extent that dryland owners share unobservable characteristics with wetland owners and service workers share unobservable characteristics with government workers, examining the reduced-form relationship between the placebo instruments and changes in religious intensity serves as a check of the identification assumption.

The placebo instruments and the actual instruments share many observed characteristics and are therefore likely to share unobserved characteristics as well. Wetland and dryland hectare ownership are both strongly associated with larger family sizes and with having fewer modern amenities. Government and service workers are significantly more likely to have graduated with 8 or more years of education, to be able to read

\footnotetext{
${ }^{2}$ The overall marginal effect is calculated from$$
\frac{\delta}{\delta x} E(y \mid x)=\frac{\delta}{\delta x} P(y=1 \mid x)-\frac{\delta}{\delta x} P(y=-1 \mid x)
$$$$
\text { since }
$$

$$
\begin{aligned}
E(y \mid x) & =E(y=1) P(y=1 \mid x)+E(y=0) P(y=0 \mid x)+E(y=-1) P(y=-1 \mid x) \\
& =P(y=1 \mid x)-P(y=-1 \mid x) .
\end{aligned}
$$
}


and write, and to follow the radio or newspapers. Moreover, there is no consistent pattern on the relative strength of the correlation between the observed characteristics and the placebo and actual instruments, except on one dimension, precrisis religious intensity.

Landownership is slightly positively correlated with precrisis household religious intensity, and government and service occupations are slightly negatively correlated with precrisis household religious intensity, but the placebo instruments are much more correlated with precrisis religious intensity than the true instruments are. To the extent that precrisis religiosity may be one of the most important determinants of changes in religious intensity during the crisis, this finding suggests that these placebos are a good choice. Appendix table B3 displays the results for conditional orthogonality between precrisis religious intensity and the instruments. Each cell represents a separate OLS regression of the corresponding measure of religious intensity (described in App. A) on each instrument, hectares of wetland owned, hectares of dryland owned, government occupation dummy, and service occupation dummy. All regressions are run at the individual level. Regressions that use villagelevel measures of religious intensity control for clustering at the village level, and there does not appear to be a consistent pattern between the instruments and village religious intensity.

Wetland and dryland differ on another important dimension: the growing season. The wet season is from November to March, which mitigates the concern that wetland owners were too busy to increase pengajian during the 3-month window before August 1998, since field preparation and planting, by far the most labor-intensive activities, would have had to occur outside of May-August. Dryland crops have much longer growing seasons, which increases the likelihood that dryland owners decrease pengajian because they are too busy, but as we shall see, this is not the case.

Finally, wetland refers to any land that grows rice, so households growing nonrice crops, such as corn, cassavas, sweet potatoes, peanuts, and soybeans, would report owning dryland. In my sample, 66 percent of households own dryland and 31 percent of households own wetland. However, it is not the case that wetland and dryland can be found only in different regions of Indonesia since 25 percent of households own both wetland and dryland. This helps the identification strategy since when I use village fixed effects, I can still observe differences in wetland and dryland ownership within the same village.

Since the relative price of rice increased much more than the relative prices of other food items (Levinsohn et al. 2003) and service workers have more flexible wages than government workers, the placebo instruments should be less correlated with economic distress than the actual instruments are. The pattern of economic distress is in fact much less 
pronounced for dryland hectares and service occupation. I estimate equation (3) for the placebo instruments. An additional hectare of dryland mitigates the decrease in per capita nonfood expenditures by $\$ 0.39$ (col. 7 of table 2), about a third of the effect (\$1.13) of an additional hectare of wetland owned (col. 5). Working in the service sector is associated with much smaller and statistically insignificant $\$ 0.19$ smaller declines in per capita nonfood expenditures, whereas working in government is associated with a $\$ 2.04$ larger decline (cols. 7 and 5).

Panel B of table 3 shows that the reduced-form relationship, specified in equation (4), between the placebo instruments and pengajian change during the crisis is almost nil in all specifications. If there are adjustment costs (Chetty 2004) to choosing religious intensity, then small shocks, such as those associated with dryland ownership and service occupation, would not affect religious intensity. A striking contrast can be seen when comparing the coefficients in column 5 for the true instruments with the placebo instruments in panels $\mathrm{A}$ and $\mathrm{B}$, and this contrast exists both with and without controls (cols. 1 and 3). This finding alleviates the concern that omitted variables associated with the instruments, wetland hectares and government occupation, are correlated with changes in religious intensity.

\section{Postexperiment}

Wetland hectares and government occupation may also be associated with differential trends in religious intensity and economic change that coincide with the financial crisis. To explore whether the differential changes in religious intensity reflect differential trends and provide another check of the identification assumption, I examine whether 1 year after the crisis, between two periods without a crisis, the instruments are associated with either economic distress or changes in religious intensity. I use the change in pengajian recorded in May 1999 and the difference between expenditures in May 1999 and December 1998 (I am unable to use the panel wave that immediately follows the crisis wave because pengajian is not recorded in December 1998). As can be seen in figure 1, this period forms a natural control experiment since the $\mathrm{Rp} / \mathrm{USD}$ exchange rate moved little.

If the crisis was indeed responsible for the differential performance of government workers and wetland owners, one should not expect the same pattern of economic distress a year after the crisis. I estimate equation (3) for this period after the crisis using the same precrisis controls. Wetland hectares are associated with a statistically insignificant $\$ 0.32$ relative decline (col. 8 of table 2) compared to a $\$ 1.13$ relative improvement during the crisis (col. 5). Government workers actually display a reverse pattern of distress as households recover from the 
financial crisis relative to others. They are associated with a $\$ 3.38$ relative improvement compared to other households (cols. 8 and 5). This does not necessarily imply that government workers are recovering to precrisis levels. Their average monthly per capita nonfood expenditure in May 1999 is $\$ 8.30$ compared to $\$ 12.90$ in May 1997. Nor are households as a whole recovering completely from the crisis. The crisis summary statistics in Appendix table B2 indicate only partial recovery on average.

Since government workers display a strong improvement relative to others, we should expect a relative decrease in pengajian during this period. I estimate equation (4) for wetland hectares and government occupation a year after the crisis. Panel C of table 3 indicates that after the crisis, neither the amount of wetland owned nor government occupation is strongly correlated with pengajian change. Government workers display a negative coefficient for pengajian (col. 5). Dryland hectares and service workers are not correlated with expenditure changes or pengajian changes during this period. In sum, it does not appear that differential trends in religious intensity associated with the instruments, wetland hectares and government occupation, explain the differential change in religious intensity.

\section{Two-Stage Least Squares (2SLS) Estimates}

In what follows, I use the exhibited pattern of distress to calculate the impact of a dollar of per capita nonfood expenditure change on changes in religious intensity. Table 4 estimates equation (2) for pengajian in linear, ordered probit, and probit specifications. ${ }^{3}$ Column 7 suggests that a $\$ 1.00$ decline in per capita nonfood expenditure stimulates a 2percentage-point increase in the likelihood of increasing pengajian. Since the average household suffered a $\$ 4.70$ decline in per capita nonfood expenditure out of a precrisis average of $\$ 7.33$ (see App. table B2; the median household suffered a $\$ 2.94$ shock out of a precrisis median of $\$ 4.75$ monthly nonfood per capita expenditures), this suggests that economic distress caused the average household to become 9 percentage points more likely to increase pengajian during the crisis. The consistency across controls suggests that remaining omitted variables bias may be small (compare cols. 3 and 4 with cols. 5 and 6). The estimates of the linear probability model displayed in the first row are very similar to the overall ordered probit marginal effects displayed in the second row. Since pengajian is measured in changes and no precrisis data on pengajian are available, it is difficult to interpret a household's

\footnotetext{
${ }^{3}$ I used Stata programs implementing Amemiya generalized least squares estimators for probits with endogenous regressors. Newey (1987) provides the formulas used. I modified these Stata programs to run ordered probits as well.
} 


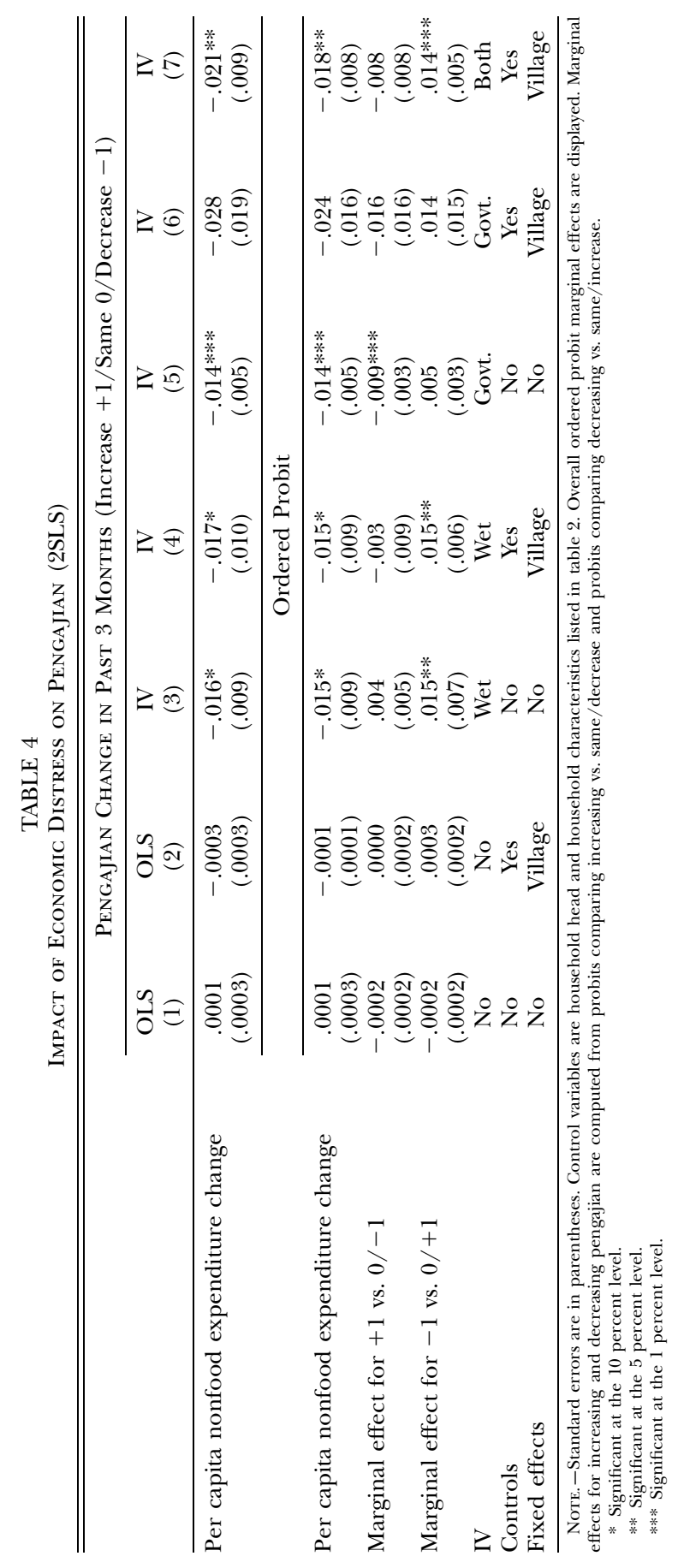


9-percentage-point greater likelihood of increasing pengajian; however, as noted in Appendix table B1, 9 percent of households increase pengajian and 9 percent of households decrease pengajian in August 1998. This suggests that economic distress, as channeled through wetland ownership and government occupation, could explain half of the increase in pengajian.

Importantly, the estimates using wetland hectares and government occupation as separate instruments are very similar, which acts as an overidentification test (compare cols. 3 and 4 with cols. 5 and 6). The Sargan overidentification statistic is 0.299 and the $p$-value is 0.585 , which indicates that the null hypothesis of both instruments being exogenous (or, more precisely, given the exogeneity of one instrument, the other is also exogenous) to changes in pengajian cannot be rejected at the 10 percent level. Since instrumental variables (IV) estimates represent only the change in behavior for those most affected by the instrument, a priori, one could imagine that an estimate based on government workers might represent only a small fraction of the population and thus be difficult to generalize. However, a marginal unit of wetland should benefit any household. Since the treatment effects for two very different populations are so similar, it suggests that the estimated elasticity may be interpreted as one that represents the entire population.

Probit marginal effects for increasing $(+1$ vs. $0 /-1)$ and decreasing $(-1$ vs. $0 /+1)$ religious intensity are displayed in the third row. When the source of variation is hectares of wetland, doing better causes a decrease in pengajian, as indicated by columns 3 and 4 . When the source of variation is government workers, larger economic distress causes an increase in pengajian, as indicated by columns 5 and 6 . The differences between the marginal effects for increasing and the marginal effects for decreasing are also similar to the estimates from the linear model in row 1 .

Columns 1 and 2 presents OLS estimates of equation (2). These estimates of the correlation between economic distress and changes in religious intensity are close to zero. The sign flips from column 1 to column 2 as controls are added, which suggests that omitted variables may play an important role. Moreover, measurement error in expenditures, which may be exacerbated in differences, also biases OLS estimates toward zero.

\section{E. Islamic Schools}

Having established that economic distress stimulates pengajian, I now turn to the other measure of religious intensity that is measured in changes, sending one's children to Islamic school, a measure that may even have intergenerational ramifications. Returns to schooling at Is- 
TABLE 5

Impact of Economic Distress on Islamic School Attendance (2SLS)

\begin{tabular}{|c|c|c|c|c|}
\hline & $\begin{array}{l}\text { OLS } \\
(1)\end{array}$ & $\begin{array}{c}\text { OLS } \\
(2)\end{array}$ & $\begin{array}{l}\text { IV } \\
(3)\end{array}$ & $\begin{array}{l}\text { IV } \\
(4)\end{array}$ \\
\hline & \multicolumn{4}{|c|}{ A. Islamic School Attendance Change } \\
\hline \multirow[t]{2}{*}{ Per capita nonfood expenditure change } & $\begin{array}{l}.000 \\
(.000)\end{array}$ & $\begin{array}{r}-.000 \\
(.000)\end{array}$ & $\begin{array}{c}-.008 * \\
(.004)\end{array}$ & $\begin{array}{c}-.010 * \\
(.006)\end{array}$ \\
\hline & \multicolumn{4}{|c|}{ B. Secular School Attendance Change } \\
\hline Per capita nonfood expenditure change & $\begin{array}{l}.000 \\
(.001)\end{array}$ & $\begin{array}{c}-.000 \\
(.001)\end{array}$ & $\begin{array}{c}-.005 \\
(.008)\end{array}$ & $\begin{array}{l}.007 \\
(.012)\end{array}$ \\
\hline IV & No & No & Both & Both \\
\hline Controls & No & Yes & No & Yes \\
\hline Fixed effects & No & Village & No & Village \\
\hline \multicolumn{5}{|c|}{$\begin{array}{l}\text { NotE. - Standard errors are in parentheses. Control variables are household head and household characteristics listed } \\
\text { n table 2. Islamic school attendance is defined as the number of children households send to Islamic schools. Only } \\
\text { nouseholds with children attending school before the crisis are included in the sample. Secular school attendance is } \\
\text { defined similarly. } \\
* \text { Significant at the } 10 \text { percent level. } \\
\text { ** Significant at the } 5 \text { percent level. } \\
* * * \text { Significant at the } 1 \text { percent level. }\end{array}$} \\
\hline
\end{tabular}

lamic schools are lower than at non-Islamic schools (Berman and Stepanyan 2003), and in the Hundred Villages Survey, parents report paying substantially larger fees at Islamic schools than at non-Islamic schools, so an increase in Islamic school attendance would be remarkable.

I find that households suffering greater economic distress increase the number of children sent to Islamic schools and decrease the number of children sent to secular schools. Only households that sent children to school before the crisis are included in the sample, which reduces the sample size to 4,255 households. Estimates suggest that households that experience a $\$ 1.00$ decline in per capita nonfood expenditures are roughly 1 percentage point more likely to switch a child to Islamic school (cols. 3 and 4 of table 5, panel A) and roughly 1 percentage point more likely to switch a child from secular school (cols. 3 and 4 of table 5, panel B). The estimates are not symmetric since households may also take children into and out of school. Increases in Islamic school attendance are statistically significant at the 10 percent level. The Sargan overidentification statistic is 0.279 and the $p$-value is 0.597 , meaning that the null hypothesis of both instruments being exogenous to changes in Islamic school attendance cannot be rejected at the 10 percent level. The consistency across controls suggests that remaining omitted variables bias may be small (compare cols. 3 and 4). Replicating the placebo and postexperiments for Islamic schools as in table 3 indicates that the point estimates are a small fraction of the point estimates for the main experiment (App. table B4), which serves as a check of the identification 
assumption for Islamic schools. The results are qualitatively similar using the percentage of children attending Islamic school. ${ }^{4}$

The average household suffered a $\$ 4.70$ decline, so the average household was roughly 5 percentage points more likely to switch a child to Islamic school, out of a baseline of 0.15 children per household attending Islamic school in May 1997, a sizable fraction. Islamic schools also become relatively more expensive over the survey time frame: parents pay a relatively constant $\$ 0.45$ per month or 2 percent of total expenditures (monthly per capita expenditure in May 1997 was $\$ 20.90$ ) at non-Islamic schools, whereas the fee for Islamic schools increased from being 35 percent higher in December 1998 to 80 percent higher than the fee for non-Islamic schools in August 1999. This increase in Islamic school fees may reflect an increasing demand for Islamic schools. It may also reflect increases in voluntary payments to Islamic schools. According to an interview at one religious school in a village in the Hundred Villages Survey, nominal minimal fees are set, yet families can contribute any amount beyond the minimum. Moreover, children who cannot afford school fees may be provided scholarships, suggesting another form of consumption smoothing provided by religious schools.

Consistent with an increasing demand, according to a 1992 Library of Congress report, an upper bound of 17 percent of the Muslim schoolage population attended Islamic schools in $1992 .{ }^{5}$ According to the IFLS survey, conducted in 1997, 18 percent of Muslim households with children attending school have sent children to an Islamic school. But according to a nationwide poll conducted in 1999, 30 percent of Muslim households with school-aged children sent their children to an Islamic school (Wagner 1999). These snapshots of time suggest that the financial crisis coincided with a sharp increase in Islamic school attendance (consistent with Hartono and Ehrmann [2001]), which seems remarkable because of potential long-term effects on children's beliefs.

\footnotetext{
${ }^{4}$ Identical results are also obtained if I run the standard specification analogous to eq. (1):$$
M_{i j t}=\beta E_{i j t}+\alpha_{0 t}+\alpha_{1 t}^{\prime} \mathbf{X}_{i j}+\delta_{j t}+u_{i}+\varepsilon_{i j t}
$$

for $t=1,2, i=1, \ldots, N$, and $j=1, \ldots, J$, where $M_{i j t}$ represents the number of children sent to Islamic school (madrasah) by household $i$ in village $j$ at time $t$, and per capita nonfood expenditures $E_{i j t}$ are instrumented by $\mathbf{Z}_{i j}$ Post $_{t}$. The variable Post $t_{t}$ is a dummy indicating whether the time period is after the crisis. Household fixed effects are represented by $u_{i}$.

${ }^{5}$ The upper bound of 17 percent results from dividing 15 percent, the overall percentage of school-age population attending Islamic school in the Library of Congress report, by 87 percent, the proportion of the population that is Muslim.
} 


\section{F. Other Social Activities}

A question that naturally arises is whether pengajian captures religious intensity or is just another social activity. In table 6, I compare pengajian with all the other social activities that are surveyed. Column 1 displays the earlier result (from col. 7 of table 4 ) that economic distress stimulates pengajian. Columns 2-6 indicate that economic distress stimulates less participation in every other social activity surveyed in my data: sports (olahraga), burial society (kematian), clubs for obtaining skills (karang taruna), family welfare movement (PKK and "occasional training for women"), and "10 helps for housing" (dasawisma). The information at the bottom of table 6 indicates that three of the activities are also free, suggesting that their smaller increase is not a result of activity fees. Moreover, sports, clubs for learning skills, and PKK are also available in 83-96 percent of villages. Since 83 percent of villages have Islamic chapels or mosques, the small or no increase in other activities is not due to the lack of available facilities.

This evidence suggests that opportunity cost of time (Azzi and Ehrenberg 1975; Gruber 2004; Gruber and Hungerman 2008) alone cannot explain the increase in religious intensity, since economic distress should also stimulate other social activities. Significantly, column 7 of table 6 indicates that economic distress does not stimulate participation in another mutual insurance group, rotating savings clubs (arisan). This result is consistent with the explanation that rotating savings clubs have much weaker social sanctions than religious groups. Mean changes are indicated in the third row of table 6. More people overall reported decreasing rotating savings club participation (col. 7) than reported increasing it, suggesting that mutual insurance groups without strong social sanctions are in fact declining relative to pengajian.

\section{G. Labor Supply}

Another question that naturally arises is whether pengajian increases during the financial crisis reflect people having more leisure. In table 7, I examine whether wetland owners supply more labor and government workers supply less labor than others during the crisis; in particular, I estimate the reduced-form analogue of equation (4). Instead of regressing

$$
\Delta L_{i j}=\beta^{\prime} \mathbf{Z}_{i j}+c+\alpha^{\prime} \mathbf{X}_{i j}+\gamma_{j}+\varepsilon_{i j},
$$

where $\Delta L_{i j}$ indicates labor supply change for household $i$ in village $j$, I estimate the equivalent specification:

$$
\begin{gathered}
L_{i j t}=\beta^{\prime} \mathbf{Z}_{i j} \text { Post }_{t}+\alpha_{0 t}+\alpha_{1 t}^{\prime} \mathbf{X}_{i j}+\delta_{j t}+u_{i}+\varepsilon_{i j t} \\
\text { for } t=1,2, i=1, \ldots, N, \text { and } j=1, \ldots, J,
\end{gathered}
$$




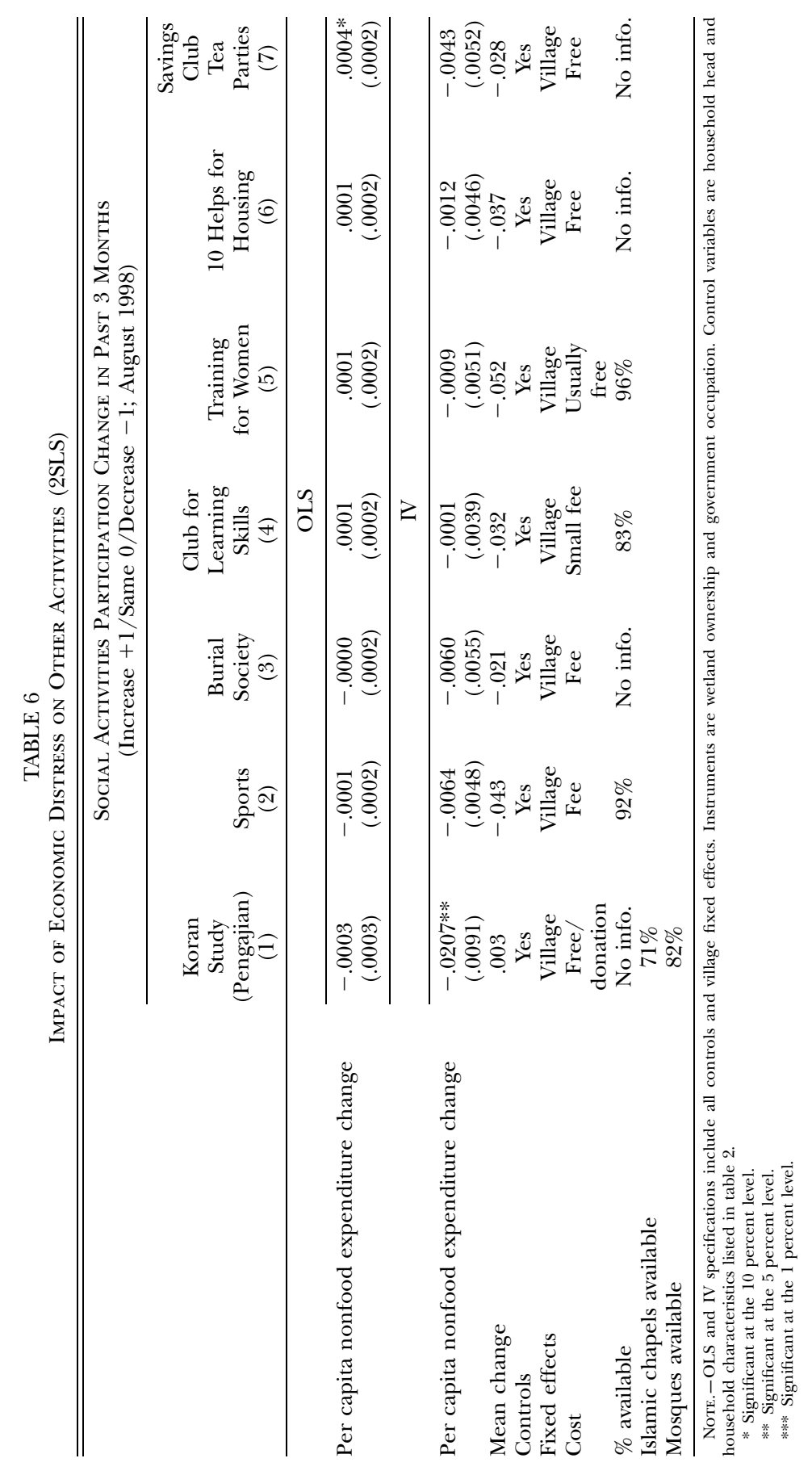


TABLE 7

Reduced-Form Relationship between Instruments and Labor Supply Change

\begin{tabular}{|c|c|c|c|c|c|}
\hline & \multicolumn{5}{|c|}{$\begin{array}{l}\text { Average HouseHold Hours Worked/WeEk } \\
\text { (May 1997, August 1998) }\end{array}$} \\
\hline & $\begin{array}{l}\text { OLS } \\
(1)\end{array}$ & $\begin{array}{l}\text { OLS } \\
(2)\end{array}$ & $\begin{array}{l}\text { OLS } \\
(3)\end{array}$ & $\begin{array}{l}\text { OLS } \\
(4)\end{array}$ & $\begin{array}{l}\text { OLS } \\
(5)\end{array}$ \\
\hline Wetland $\times$ post & $\begin{array}{l}-.95 * * \\
(.39)\end{array}$ & $\begin{array}{l}-.93^{* *} \\
(.39)\end{array}$ & & & $\begin{array}{l}-.92 * * \\
(.39)\end{array}$ \\
\hline Government $\times$ post & & & $\begin{array}{l}3.19 * * * \\
(.81)\end{array}$ & $\begin{array}{c}-1.13 \\
(1.06)\end{array}$ & $\begin{array}{c}-1.09 \\
(1.06)\end{array}$ \\
\hline Post & $\begin{array}{l}21.21 * * * \\
(.21)\end{array}$ & $\begin{array}{l}14.99 * * * \\
(2.22)\end{array}$ & $\begin{array}{l}20.83 * * * \\
(.21)\end{array}$ & $\begin{array}{l}15.40 * * * \\
(2.22)\end{array}$ & $\begin{array}{l}15.00 * * * \\
(2.22)\end{array}$ \\
\hline Controls & No & Yes & No & Yes & Yes \\
\hline Fixed effects & Household & Household & Household & Household & Household \\
\hline
\end{tabular}

where Post $t_{t}$ is a dummy variable indicating whether the time period is after the crisis, $L_{i j t}$ indicates labor supply for household $i$ in village $j$ in time $t$, and $u_{i}$ represents household fixed effects (the notation is like that of eq. [1]). This specification highlights the overall labor supply change for the entire population, captured in $\alpha_{0}$. Previous regressions are not run this way because pengajian data are available only in changes.

The coefficient on Post ${ }_{t}$ in table 7 indicates that all households increased labor supply, as measured by average household hours worked per week. The magnitudes suggest that people are switching from home production to market production. This is consistent with Frankenberg et al.'s (1999) finding that female employment increased during the crisis and that a large number of women joined the informal workforce or family businesses (including working on the family farm). In fact, dividing 21 (coefficient on Post ${ }_{t}$ in col. 1) by 7 days a week and multiplying by the average number of working-age household members (4.16 average household size - 1.79 average number of children in school $=2.37$ ) gives an increase in labor supply of just over 7 hours a day, equivalent to perhaps one woman per household leaving home production and entering the workforce. Columns 1 and 3 indicate that those who were hit harder by economic distress increased their labor supply relative to others (suggesting a backward-bending labor supply), inconsistent with the notion that pengajian increases because people have more leisure. With controls, the coefficient for wetland remains significant, but not for government workers. ${ }^{6}$

\footnotetext{
${ }^{6}$ Controlling for ownership of modern amenities particularly affects the coefficient on government workers. One possible explanation is that owners of modern amenities may have access to additional means of increasing household labor supply.
} 


\section{Does Religious Intensity Function as Ex Post Social Insurance?}

Sections III and IV establish that economic distress stimulates religious intensity. But neither a decrease in the opportunity cost of time nor extra leisure time appears to explain the increase in religious intensity: there is a minimal corresponding increase in any other social activity, and labor supply does not decrease for households more affected by the crisis. In fact, it is not that people on the margin reduce labor and increase religious intensity but that they increase labor, and within nonlabor allocation, they substitute toward religion.

In this section, I now turn to the evidence that religion provides ex post insurance, consistent with the model discussed in Section II. Some of the benefits of religious insurance groups may be in-kind, such as the matching of the unemployed to employers, so I do not rely on data on transfers between households, which the Hundred Villages Survey does not contain, in presenting evidence that households receive aid from religious groups immediately after increasing their religious intensity. I show that (1) an increase in religious intensity, within 4 months, alleviates household need for credit; (2) households with alternative forms of credit available do not increase their religious intensity in response to economic distress; (3) households with additional religious institutions available have smaller variance in their consumption shocks due to the crisis; (4) religious institutions mitigate the effect of the income shocks on consumption shocks; and (5) religious institutions smooth consumption shocks particularly for households that were previously less religious before the crisis.

\section{A. Do Religious Institutions Provide Aid Ex Post?}

Households that increase religious intensity during the peak of the crisis reduce the likelihood of being credit constrained. A household is considered as needing alms or credit to meet basic daily needs if it does not have basic supplies for next week or a supply of money; so in order to get food, family members are waiting for a package, (trying to) borrow from someone else, or waiting for someone to give (the variable construction is described in greater detail in App. A). As this information is asked only after the crisis, I examine whether pengajian participation affects credit constraints by using a differences-in-differences strategy that compares credit constraints at the peak of the crisis with those for a few months afterward. In table 8 , I present summary statistics by group that is similar to the organization of table 1 . Columns 1 and 2 show the mean level of credit constraints in August and December of 1998, for different categories of pengajian activity: increase, constant, decrease, or no participation in the 3 months before August 1998. Column 3 
TABLE 8

Evidence Suggesting Religious Intensity Functions as Social Insurance: Credit Constraints by Group (August 1998)

\begin{tabular}{|c|c|c|c|}
\hline & \multicolumn{2}{|c|}{ Credit Constrained } & \multirow{2}{*}{$\begin{array}{c}\text { Change } \\
\text { IN Credit } \\
\text { Constraints } \\
(3)\end{array}$} \\
\hline & $\begin{array}{c}\text { August } \\
1998 \\
\text { (1) }\end{array}$ & $\begin{array}{c}\text { December } \\
1998 \\
(2)\end{array}$ & \\
\hline Increase participation $(N=753)$ & $\begin{array}{c}.039 \\
(.007)\end{array}$ & $\begin{array}{l}.020 \\
(.005)\end{array}$ & $\begin{array}{c}-.019 \\
(.008)\end{array}$ \\
\hline Constant participation $(N=3,509)$ & $\begin{array}{c}.043 \\
(.003)\end{array}$ & $\begin{array}{c}.032 \\
(.003)\end{array}$ & $\begin{array}{c}-.010 \\
(.004)\end{array}$ \\
\hline Decrease participation $(N=728)$ & $\begin{array}{c}.034 \\
(.007)\end{array}$ & $\begin{array}{c}.028 \\
(.006)\end{array}$ & $\begin{array}{c}-.007 \\
(.009)\end{array}$ \\
\hline No participation $(N=3,148)$ & $\begin{array}{c}.052 \\
(.004)\end{array}$ & $\begin{array}{c}.049 \\
(.004)\end{array}$ & $\begin{array}{c}-.003 \\
(.005)\end{array}$ \\
\hline Difference $(N=8,138)$ & $\begin{array}{c}-.004 \\
(.002)\end{array}$ & $\begin{array}{c}-.009 \\
(.002)\end{array}$ & $\begin{array}{c}-.005 \\
(.003)\end{array}$ \\
\hline
\end{tabular}

NoTE.-Standard errors are in parentheses. Coefficients display group means. Difference displays the regression coefficient of the change in credit constraints on participation, where increase participation $=4$, constant participation $=3$, decrease participation $=2$, and no participation $=1$.

shows the means of changes in likelihood of being credit constrained for each category of pengajian activity.

Several important features of the data can be observed. Households that increase participation in Koran study during the crisis (May-August 1998) see a 49 percent reduction in the likelihood of needing alms or credit 4 months later (in December 1998), whereas households that report constant Koran study are 23 percent less likely to need alms or credit 4 months later and households that decrease participation see a 21 percent reduction in the likelihood of needing alms or credit 4 months later. Households that did not participate in pengajian are only 6 percent less likely to need alms or credit 4 months later. The final row in table 8 presents an imprecise estimator of the impact of pengajian on credit constraints by regressing the change in credit constraints on pengajian activity, where increase participation $=4$, constant participation $=3$, decrease participation $=2$, and no participation $=1$. I find that each category of pengajian activity reduces credit constraints by 0.5 percentage points shortly after the peak of the financial crisis.

Two features of the data suggest that mean reversion is not the reason for the differential reduction in credit constraints during the crisis, where those who were hardest hit may be most likely to increase religious intensity, yet naturally most improve in credit constraints thereafter. First, nonparticipating households, which were the most credit constrained, show the smallest decline in needing alms or credit 3 months later. Mean reversion would predict these households to have the biggest decline in credit constraints. Second, rates of credit constraints among households are diverging after the crisis. In August 1998, the percentage 
of households that were credit constrained varied from 3.4 percent to 5.2 percent among the different groups by pengajian activity, and in December 1998, the percentage of households that were credit constrained varies in a larger range, from 2.0 percent to 4.9 percent, but mean reversion would predict convergence in the rate of credit constraints.

These findings of ex post aid are not limited to these measures of religious activity or economic welfare. Results for Islamic school attendance are analogous: households that increase Islamic school attendance have greater reductions in the likelihood of needing alms or credit than households with constant or decreasing Islamic school attendance. Similar results are found using nonfood expenditures as the outcome variable instead of credit constraints.

Elsewhere, I have noted anecdotal evidence from personal interviews of religious groups providing aid after negative shocks are revealed. Pengajian groups simultaneously increase attendance and provide public announcements to aid those seeking jobs or workers. Islamic schools induce higher attendance with scholarships for families who can no longer afford public school fees. Together, these pieces of evidence corroborate the notion that religious intensity alleviates needing alms or credit to meet basic needs.

\section{B. Does Religious Intensity Increase in Response to Lack of Credit?}

The model described in Section II suggests that religious intensity does not respond to economic distress if alternative forms of consumption smoothing are available. To investigate this hypothesis, I estimate

$$
\Delta Q_{i j}=\beta_{0} \Delta E_{i j}+\beta_{1}\left(\Delta E_{i j} C_{j}\right)+\alpha_{0} C_{j}+\alpha_{1}^{\prime} \mathbf{X}_{i j}+\gamma_{j}+\varepsilon_{i j},
$$

where $C_{j}$ represents credit availability in village $j$, and credit availability, according to residents of Indonesia, is defined as having banks, microfinance institutions, or BRI loan products. The BRI bank system is the backbone of the rural financial system in Indonesia (Holloh 2001), and BRI loan products are a special form of credit (with reduction of interest for timely repayments) with low collateral requirements. According to one interview at a village in the Hundred Villages Survey, BRI loan products were especially available during the crisis for government workers because they were considered to have "fixed" jobs. Microfinance programs were also helpful for laid-off workers to start small businesses of their own (AKATIGA 1999).

The coefficient of the interaction $\Delta E_{i j} C_{j}$ indicates whether the effect of economic distress on religious intensity decreases with the availability of credit. The coefficient is negative and significant. The estimate is robust to specifications with and without controls (cols. 1 and 2 of table 
TABLE 9

Evidence Suggesting Religious Intensity Functions as Social Insurance: Credit

\begin{tabular}{|c|c|c|c|c|}
\hline & \multicolumn{4}{|c|}{$\begin{array}{c}\text { Pengajian Change in Past } 3 \text { Months } \\
\text { (August 1998) }\end{array}$} \\
\hline & $\begin{array}{l}\text { IV } \\
(1)\end{array}$ & $\begin{array}{l}\text { IV } \\
(2)\end{array}$ & $\begin{array}{l}\text { IV } \\
(3)\end{array}$ & $\begin{array}{l}\text { IV } \\
(4)\end{array}$ \\
\hline $\begin{array}{l}\text { Per capita nonfood expenditure } \\
\text { change }\end{array}$ & $\begin{array}{l}-.018 * * * \\
(.007)\end{array}$ & $\begin{array}{l}-.037 * * * \\
(.014)\end{array}$ & $\begin{array}{c}-.026 \\
(.022)\end{array}$ & $\begin{array}{r}-.024 * \\
(.013)\end{array}$ \\
\hline $\begin{array}{l}\text { Per capita nonfood expenditure } \\
\text { change } \times \text { credit availability }\end{array}$ & $\begin{array}{l}.021 * * * \\
(.008)\end{array}$ & $\begin{array}{l}.030^{* *} \\
(.013)\end{array}$ & $\begin{array}{l}.030 * \\
(.018)\end{array}$ & \\
\hline $\begin{array}{l}\text { Per capita nonfood expenditure } \\
\text { change } \times \text { number of shops per } \\
1,000 \text { population }\end{array}$ & & & $\begin{array}{l}(.021) \\
(.071)\end{array}$ & \\
\hline $\begin{array}{l}\text { Per capita nonfood expenditure } \\
\text { change } \times \text { urban }\end{array}$ & & & $\begin{aligned}-.011 \\
(.026)\end{aligned}$ & \\
\hline $\begin{array}{l}\text { Per capita nonfood expenditure } \\
\text { change } \times \text { size of village }\end{array}$ & & & $\begin{array}{c}-.005 \\
(.006)\end{array}$ & \\
\hline $\begin{array}{l}\text { Per capita nonfood expenditure } \\
\text { change } \times \text { village population }\end{array}$ & & & $\begin{array}{c}-.012 \\
(.031)\end{array}$ & \\
\hline $\begin{array}{l}\text { Per capita nonfood expenditure } \\
\text { change } \times \text { high savings }\end{array}$ & & & & $\begin{array}{l}.025^{*} \\
(.014)\end{array}$ \\
\hline Controls & No & Yes & Yes & Yes \\
\hline Fixed effects & No & Village & Village & Village \\
\hline
\end{tabular}

NoTE.-Standard errors are in parentheses. Instruments are wetland ownership, government, their interaction with credit availability (in cols. 1-3), their interaction with listed village characteristics (col. 3), and their interaction with high savings (col. 4). Credit availability is defined as having a bank, microfinance, or BRI loan product available in the village. High savings is defined as those villages that have an above-median fraction of households with savings. Control variables are household head and household characteristics listed in table 2.

* Significant at the 10 percent level.

** Significant at the 5 percent level.

*** Significant at the 1 percent level.

9). Dividing 0.30 by 0.37 in column 2 suggests that credit availability reduces the effect of economic distress on religious intensity by roughly 80 percent. When I cluster standard errors at the village level to account for the fact that credit availability is measured at the village level, this reduction remains statistically significant at the 10 percent level. The Sargan overidentification statistic is 3.610 and the $p$-value is 0.461 , which indicates that the null hypothesis that the instruments interacted with credit availability are exogenous to changes in pengajian cannot be rejected at the 10 percent level. Credit availability also reduces the effect of economic distress on switching children from secular to Islamic schools, but the effect is not statistically significant.

To address the possibility that credit availability proxies for general economic development, I employ two strategies: one that includes ad- 
ditional control variables that may proxy for economic development and a second that uses an alternative measure for credit availability. In the first strategy, I include interactions between economic distress and the number of shops, an urban dummy, size of village, and village population, respectively. The standard errors of the coefficients of interest, $\beta_{0}$ and $\beta_{1}$, increase (in col. 3), and the magnitudes do not change much (the coefficients indicate that credit availability effectively eliminates the effect of economic distress on religious intensity). This suggests that there is something particular about credit availability, not economic development, that influences how economic distress stimulates religious intensity. In the second strategy, I use reports by village heads of the fraction of households in the village that have savings as an alternative measure of credit availability. In column 4, I use the interaction of economic distress with an indicator for whether the village is above the median in the fraction of households that have savings. I find that credit availability reduces the effect of economic distress on religious intensity by roughly 100 percent. When I cluster standard errors at the village level, this reduction remains statistically significant at the 10 percent level.

Religious intensity may have increased most where insurance is lacking. Remarkably, the proportion of households participating in pengajian increased from 47 percent to 73 percent from August 1998 to August 1999 where there were no Islamic chapels or mosques. Elsewhere, the proportion of households participating in pengajian increased only from 64 percent to 71 percent. Similar statistics are found for villages with and without credit availability and for villages with or without many households that save (App. table B1). Pengajian participation increased from 60 percent to 71 percent in villages without credit but increased from 63 percent to 72 percent in villages with credit. Pengajian participation increased from 60 percent to 73 percent in villages with low savings but increased from 62 percent to 70 percent in villages with high savings.

Having shown that religious intensity increases in response to lack of credit and that religious intensity alleviates credit constraints, I now turn to tests of social insurance provision by religious institutions at the village level.

\section{Do Religious Institutions Smooth Consumption Shocks?}

Up to this point, the paper has examined household responses to economic distress and household measures of religious intensity. In this subsection, I examine the effect of religious institutions on a villagelevel measure of economic distress: if religious institutions provide social insurance, villagers will smooth more of their consumption shocks with 
each other. So did the crisis have a smaller impact on the spread of consumption changes in places where there were more religious institutions? To test this hypothesis, I identify an exogenous component of the financial crisis based on the village-level version of the instrumentthe Gini coefficient of wetland hectares. Since wetland hectares cushion household economic distress, the Gini coefficient of wetland ownership within a village identifies the inequality of economic cushioning during the crisis. In this subsection, I ask whether this exogenous crisis component (Gini coefficient of wetland) interacted with the precrisis number of worship buildings is negatively associated with the impact of the crisis on the standard deviation of consumption shocks.

The model described in Section II suggests the following reducedform specification:

$$
\begin{gathered}
\operatorname{Crisis\_ } \_\operatorname{Stdev}\left(\Delta E_{i j}\right)_{j}-\operatorname{Noncrisis\_ } \operatorname{Stdev}\left(\Delta E_{i j}\right)_{j}= \\
\beta_{0} I_{j}+\beta_{1}^{\prime} I_{j} \mathbf{S}_{j}+\alpha_{0}^{\prime} \mathbf{S}_{j}+\alpha_{1}^{\prime} \mathbf{X}_{j}+\kappa_{p}+\eta_{j p},
\end{gathered}
$$

where $\operatorname{Stdev}\left(\Delta E_{i j}\right)_{j}$ is constructed by calculating each household's change in monthly per capita nonfood consumption expenditures and then computing the village-level standard deviation of these consumption shocks; Crisis_Stdev $\left(\Delta E_{i j}\right)_{j}$ is computed using the consumption shocks during the financial crisis; $\operatorname{Noncrisis} \_\operatorname{Stdev}\left(\Delta E_{i j}\right)_{j}$ is computed using consumption shocks during the postexperiment described earlier. The standard deviation captures consumption smoothing among villagers. Differencing addresses potential fixed omitted variables associated with village consumption smoothing. The term $I_{j}$ represents the villagelevel instrument, the Gini coefficient of wetland hectares, and $\mathbf{S}_{j}$ represents potential social insurance institutions, total number of worship buildings per 1,000 population, 1996-97 INPRES (Presidentially Instructed Program for Village Assistance) funds per 1,000 population, and credit availability, as well as characteristics about the village that may be plausibly correlated with both religious worship buildings and the standard deviation of consumption shocks during the crisis. The term $\mathbf{X}_{j}$ represents village and geographic controls (urban dummy, population, area, number of shops per 1,000 population, mean precrisis monthly per capita nonfood expenditures, and dummies for geographic characteristics flat, steep, beach, forest, valley, and river), and $\kappa_{p}$ represents province fixed effects.

In the previous subsection, I showed that credit availability lowered the effect of economic distress on religious intensity. Here, using an analogous specification, I ask, Do worship buildings lower the effect of the wetland Gini coefficient on the standard deviation of consumption shocks? As a preliminary step, I first show that there is a strong reducedform relationship between the wetland Gini coefficient and the standard 
TABLE 10

Evidence Suggesting Religious Intensity Functions as Social Insurance: Consumption Smoothing among Villagers

\begin{tabular}{|c|c|c|c|c|}
\hline & \multicolumn{4}{|c|}{$\begin{array}{c}\text { Change in STANDARD Deviation of } \\
\text { Consumption SHOck }\end{array}$} \\
\hline & $\begin{array}{l}\text { OLS } \\
(1)\end{array}$ & $\begin{array}{l}\text { OLS } \\
(2)\end{array}$ & $\begin{array}{l}\text { OLS } \\
(3)\end{array}$ & $\begin{array}{l}\text { OLS } \\
(4)\end{array}$ \\
\hline Wetland Gini & $\begin{array}{l}18.08^{* *} \\
(7.97)\end{array}$ & $\begin{array}{l}40.58^{* * * *} \\
(12.85)\end{array}$ & $\begin{array}{l}24.35^{* * *} \\
(8.43)\end{array}$ & $\begin{array}{l}25.89 \\
(23.24)\end{array}$ \\
\hline $\begin{array}{l}\text { Wetland Gini } \times \text { worship buildings } \\
\text { per } 1,000 \text { population }\end{array}$ & & $\begin{array}{l}-7.47 * * \\
(3.75)\end{array}$ & & $\begin{array}{r}-8.99 * \\
(4.68)\end{array}$ \\
\hline $\begin{array}{l}\text { Wetland Gini } \times 1996-97 \text { INPRES } \\
\text { funds }(\$ / 1,000 \text { population })\end{array}$ & & & & $\begin{array}{c}21.48 \\
(16.63)\end{array}$ \\
\hline Wetland Gini $\times$ credit availability & & & & $\begin{array}{c}43.20 \\
(26.53)\end{array}$ \\
\hline Wetland Gini $\times$ urban & & & & $\begin{array}{l}21.16 \\
(26.13)\end{array}$ \\
\hline $\begin{array}{l}\text { Wetland Gini } \times \text { number of shops } \\
\text { per } 1,000 \text { population }\end{array}$ & & & & $\begin{array}{l}23.60 \\
(30.84)\end{array}$ \\
\hline Wetland Gini $\times$ size of village & & & & $\begin{array}{r}-14.41 \\
(18.46)\end{array}$ \\
\hline $\begin{array}{l}\text { Wetland Gini } \times 1996-97 \text { INPRES } \\
\text { economic funds }(\$ / 1,000 \\
\text { population })\end{array}$ & & & & $\begin{array}{c}-57.21 \\
(42.40)\end{array}$ \\
\hline Village, geographic controls & No & No & Yes & Yes \\
\hline Fixed effects & No & No & Province & Province \\
\hline \multicolumn{5}{|c|}{$\begin{array}{l}\text { NoTE.-Village-level regressions. Standard errors are in parentheses. Controls are village and geographic character- } \\
\text { istics listed below. Wetland Gini refers to the Gini coefficient of wetland ownership. Change in standard deviation of } \\
\text { consumption shock is computed by considering the per capita nonfood consumption expenditure shock households } \\
\text { received between two periods over the crisis and taking the standard deviation of those household shocks for each } \\
\text { village. Then the same standard deviation of consumption shocks is computed for two periods without an intervening } \\
\text { crisis, the periods used for the postexperiment earlier in the paper. The difference between the crisis standard deviation } \\
\text { and the noncrisis standard deviation is the variable of interest. Standard deviation captures consumption smoothing in } \\
\text { a village. Differencing addresses potential fixed omitted variables associated with consumption smoothing. Columns } 1 \\
\text { and } 3 \text { show that wetland Gini is strongly associated with a larger standard deviation of consumption shocks during the } \\
\text { crisis. Columns } 2 \text { and } 4 \text { display the coefficients of interest. Village characteristics: urban, population, size, number of } \\
\text { shops per } 1,000 \text { population, and mean precrisis per capita nonfood expenditures. Geographic characteristics: flat, steep, } \\
\text { beach, forest, valley, and river. }\end{array}$} \\
\hline
\end{tabular}

deviation of consumption shock due to the financial crisis (cols. 1 and 3 of table 10).

The coefficients of interest, $\beta_{0}$ and $\beta_{1}$, are displayed in columns 2 and 4. The negative sign on the interaction of the wetland Gini coefficient and worship buildings suggests that religious institutions facilitate consumption smoothing among villagers. The average number of religious worship buildings per 1,000 population is 3.83 (App. table B1, village summary statistics). Multiplying 3.83 by the coefficient 7.47 and dividing by 40.58 (col. 2) suggests that the average number of religious worship buildings reduced the effect of the financial crisis on the standard deviation of consumption shock by roughly 70 percent. Comparing columns 2 and 4 suggests that the relationship is robust to adding village 
and geographic controls and province fixed effects. In particular, column 4 shows that religious worship buildings significantly reduce the standard deviation of consumption shocks even when the interactions between the wetland Gini coefficient and, respectively, INPRES funds, credit availability, urban dummy, number of shops per 1,000 population, village size, and INPRES funds directed to economic activity are controlled for. The relationship is not robust, however, to using the coefficient of variation or interquartile range of village consumption changes. The reason may be that the mean of consumption shocks during the noncrisis period is very small, and dividing by them makes the noncrisis numbers extremely large.

Having provided some evidence of social insurance provision by religious institutions at the village level, I now turn to the question of whose consumption shocks are being insured by religious institutions. Using data on household religious intensity before the crisis, I conduct a test of whether the consumption smoothing by religious institutions is ex ante or ex post.

\section{Do Religious Institutions Smooth Individual Consumption Shocks?}

In this subsection, I begin by examining whether religious institutions reduce the effect of income shocks on consumption shocks, a standard income-consumption-translation test of insurance (Townsend 1994; Dehejia et al. 2007). The methodology developed in the previous subsection provides evidence of spatial insurance at the village level; here, I use wetland hectares and government occupation as instruments for income shocks at the household level and interact them with precrisis religious institutions to see if the latter mitigates household consumption shocks. I find that each hectare of wetland results in a $\$ 3.41$ cushion, but the average number of worship buildings per 1,000 population reduces this cushion by $\$ 2.17$, suggesting that the average number of religious worship buildings reduced the effect of the financial crisis on economic distress by 64 percent (table 11, col. 4). Government occupation results in a $\$ 2.13$ exacerbation from the crisis, and the average number of worship buildings per 1,000 population mitigates this shock by $\$ 0.81$; however, these point estimates are not statistically significant. I report conditional correlations, but unconditional correlations give similar results (col. 2). When I cluster standard errors at the village level, this reduction remains statistically significant at the 10 percent level. Religious institutions mitigate not only the effect of income shocks during the crisis but also the effect of income shocks after the crisis, reducing the effect of income shocks on the household standard deviation of consumption shocks across the four waves of data. 
TABLE 11

Evidence Suggesting Religious Intensity Functions as Ex Post Social INSURANGE: CONSUMPTION SMOOTHING AMONG VILLAGERS

\begin{tabular}{|c|c|c|c|c|c|c|}
\hline & \multicolumn{6}{|c|}{$\begin{array}{c}\text { Change in Per Capita Nonfood ExPenditure (\$/Month; } \\
\text { August } 1998 \text { - May 1997) }\end{array}$} \\
\hline & $\begin{array}{l}\text { OLS } \\
(1)\end{array}$ & $\begin{array}{l}\text { OLS } \\
(2)\end{array}$ & $\begin{array}{l}\text { OLS } \\
(3)\end{array}$ & $\begin{array}{l}\text { OLS } \\
(4)\end{array}$ & $\begin{array}{l}\text { OLS } \\
(5)\end{array}$ & $\begin{array}{c}\text { OLS } \\
(6)\end{array}$ \\
\hline Wetland hectares & $\begin{array}{l}1.24 * * * \\
(.42)\end{array}$ & $\begin{array}{l}3.74 * * * \\
(.89)\end{array}$ & $\begin{array}{l}1.12 * * * \\
(.36)\end{array}$ & $\begin{array}{l}3.41 * * * \\
(.78)\end{array}$ & $\begin{array}{l}4.83 * * * \\
(1.08)\end{array}$ & $\begin{array}{l}4.63 * * * \\
(.94)\end{array}$ \\
\hline $\begin{array}{l}\text { Wetland hectares } \\
\times \text { worship build- } \\
\text { ings per } 1,000 \\
\text { population }\end{array}$ & & $\begin{array}{l}-.64 * * * \\
(.20)\end{array}$ & & $\begin{array}{l}-.57 * * * \\
(.17)\end{array}$ & $\begin{array}{l}-.92 * * * \\
(.26)\end{array}$ & $\begin{array}{l}-.88^{* * * *} \\
(.22)\end{array}$ \\
\hline $\begin{array}{l}\text { Wetland hectares } \\
\times \text { worship build- } \\
\text { ings per } 1000 \\
\text { population } \\
\times \text { religious }\end{array}$ & & & & & $\begin{array}{l}.71 * \\
(.43)\end{array}$ & $\begin{array}{l}.78^{* *} \\
(.33)\end{array}$ \\
\hline Controls & No & No & Yes & Yes & No & Yes \\
\hline Fixed effects & No & No & Village & Village & No & Village \\
\hline
\end{tabular}

Nоте. - Standard errors are in parentheses. Control variables are household head and household characteristics listed in table 2. Religious households are those that attended the haj or Islamic school before the crisis. Columns 1 and 3 show that wetland hectares are strongly associated with the experience of economic distress during the crisis. Columns 2 and 4 show that the association between wetland ownership and economic distress during the crisis is mitigated with the prence of worship buildings. Columns 5 and 6 show that worship buildings mitigate the experien the presence of worship builing. Columns 5 and 6 sistress (he crisis.

Significant at the 10 percent level.

** Significant at the 5 percent level.

\section{Do Religious Institutions Provide Ex Ante Insurance?}

So far, I have provided evidence of social insurance by religious institutions, but what about ex post insurance postulated by the model described in Section II: Are nonreligious individuals able to increase religious intensity after the crisis and receive smoothing for this increase? Neither credit availability nor precrisis measures of religious institutions at the village level provide definitive answers to the question of ex ante or ex post insurance. That households that increase in pengajian had a greater reduction in credit constraints 4 months later is consistent with ex post insurance, but increasing pengajian suggests that the household was participating beforehand anyway; moreover, the finding that non-pengajian participants saw no reduction in credit constraints is consistent with either ex ante or ex post insurance.

One test of consumption smoothing consistent with a dynamic ex ante insurance story, where individuals increase their posterior beliefs on uncertainty, is whether economic distress stimulates religious intensity more when the dispersion of shocks increases. A greater dispersion of shocks might lead individuals to believe that there is greater uncertainty in the economic environment. There is some evidence that economic distress stimulates more Koran study and Islamic school atten- 
TABLE 12

Evidence Suggesting Religious Intensity Functions as Ex Post Social Insurance: The Role of Prior Religiosity and Inequality

\begin{tabular}{|c|c|c|c|c|c|c|}
\hline & \multicolumn{6}{|c|}{ Pengajian Change in Past 3 Months (August 1998) } \\
\hline & $\begin{array}{l}\text { OLS } \\
(1)\end{array}$ & $\begin{array}{l}\text { OLS } \\
(2)\end{array}$ & $\begin{array}{l}\text { OLS } \\
(3)\end{array}$ & $\begin{array}{l}\text { OLS } \\
(4)\end{array}$ & $\begin{array}{l}\text { OLS } \\
(5)\end{array}$ & $\begin{array}{l}\text { OLS } \\
(6)\end{array}$ \\
\hline Wetland hectares & $\begin{array}{l}-.036 * * * \\
(.010)\end{array}$ & $\begin{array}{l}-.046^{* * * *} \\
(.011)\end{array}$ & $\begin{array}{l}-.024 * * \\
(.010)\end{array}$ & $\begin{array}{l}-.068 * * \\
(.032)\end{array}$ & $\begin{array}{l}-.085^{* * *} \\
(.034)\end{array}$ & $\begin{array}{l}.006 \\
(.038)\end{array}$ \\
\hline $\begin{array}{l}\text { Wetland hectares } \\
\times \text { religious }\end{array}$ & $\begin{array}{l}.120 * * * \\
(.028)\end{array}$ & $\begin{array}{l}.108 * * * \\
(.029)\end{array}$ & $\begin{array}{c}.038 \\
(.027)\end{array}$ & & & \\
\hline $\begin{array}{l}\text { Wetland hectares } \\
\times \text { wetland Gini }\end{array}$ & & & & $\begin{array}{l}.070 * \\
(.042)\end{array}$ & $\begin{array}{l}.076 * \\
(.044)\end{array}$ & $\begin{array}{r}-.034 \\
(.048)\end{array}$ \\
\hline Household controls & No & Yes & Yes & No & Yes & Yes \\
\hline $\begin{array}{l}\text { Village, geographic } \\
\text { controls }\end{array}$ & No & Yes & $\begin{array}{l}\text { Village } \\
\text { fixed } \\
\text { effects }\end{array}$ & No & Yes & $\begin{array}{c}\text { Village } \\
\text { fixed } \\
\text { effects }\end{array}$ \\
\hline
\end{tabular}

NoTE. - Standard errors are in parentheses. Control variables are household head and household characteristics listed in table 2. Village and geographic controls are listed below. Religious households are those that attended the haj or Islamic school before the crisis. Wetland Gini refers to the Gini coefficient of wetland ownership. Columns 1 and 2 show that households lacking wetland hectares, which is strongly associated with the experience of economic distress show that households lacking wetland hectares, which is strongly associated with the experience of economic distress
during the crisis, increased their Koran study during the crisis, but only among the nonreligious. Columns 4 and 5 during the crisis, increased their Koran study during the crisis, but only among the nonreligious. Columns 4 and 5 show that where incomes are more unequal, Koran study increases more with economic distress. Village characteristics:
urban, population, size, number of shops per 1,000 population, and mean precrisis per capita nonfood expenditures. Geographic characteristics: flat, steep, beach, forest, valley, and river.

* Significant at the 10 percent level.

** Significant at the 5 percent level.

*** Significant at the 1 percent level.

dance in areas with a high Gini coefficient of wetland than in areas with a low Gini coefficient of wetland (table 12, cols. 4 and 5). However, the point estimates are not statistically significantly different when village fixed effects are included (col. 6).

An additional test of consumption smoothing consistent with a dynamic ex ante insurance story is whether households that were already religious are the ones that increase religious intensity in response to their economic shock. In fact, there is weak evidence that the opposite is true. Households that were religious before the crisis, measured as those in which a household member attended the haj or Islamic school, decrease pengajian if they suffered greater economic shock (table 12, cols. 1 and 2). The estimates weaken in statistical significance but do not switch signs with the inclusion of village fixed effects (col. 3). It does not appear to be the case that households that were already religious before the crisis were the ones that increased religious intensity in response to economic distress.

\section{Do Religious Institutions Provide Ex Post Insurance?}

To test for the provision of ex post insurance, I examine whether religious or nonreligious households benefit from the consumption 
smoothing provided by religious institutions. I proxy for a household's religiosity before the crisis using data on whether a household member attended the haj or Islamic school. Thirteen percent of households report having a household member who attended Islamic school or the haj before the financial crisis (App. table B1). I find that nonreligious households are the ones that benefit from religious institutions' consumption smoothing. For households that were not religious before the crisis, the average number of religious worship buildings reduced the effect of the financial crisis on consumption shock by 73 percent $(3.83 \times-0.88 / 4.63)$. For households that were religious before the crisis, the average number of religious worship buildings reduced the effect of the financial crisis by 8 percent $(3.83 \times[-0.88+0.78] / 4.63)$. This finding is robust to the inclusion of household controls and village fixed effects (table 11, cols. 5 and 6).

Moreover, under the rough assumption that precrisis households participate in pengajian if a household member attended the haj or Islamic school (it is not possible to pinpoint whether pengajian increases reflect changes on the intensive or extensive margin since precrisis pengajian information is unavailable), government workers appear to have joined pengajian studies whereas wetland owners decreased preexisting pengajian studies. In addition, as shown in Appendix table B2, pengajian participation increased by 17 percentage points from August 1998 to August 1999 for households that do not own the Koran, whereas it increased by only 8 percentage points for households that do own the Koran. This evidence taken together suggests that it is the less religious households that increase their religious participation during the crisis and receive consumption smoothing for that increase.

\section{E. Alternative Theories}

In this subsection, I consider several alternative theories to explain the findings in this paper.

\section{Distress}

While some of the social insurance evidence does suggest an economic aspect to pengajian activity, it is generally difficult to disentangle economics from distress in a situation of economic distress. I therefore test whether pengajian responds to shocks that are more distressing than economic shocks-family deaths (infants) - and find that infant deaths do not increase pengajian. This suggests that economic distress, not just any distress, is responsible for pengajian increases. It also makes it less likely that religious intensity merely provides solace or moral, emotional, and psychological support. This may seem counterintuitive to the com- 
mon notion that bad times stimulate religious feeling. However, casual observation suffers from a self-selection problem in reports: the econometrician does not observe all people who suffer distress even if the religiously intense claim that distress stimulates religiosity. A priori, distress is equally likely to decrease religious intensity.

\section{Altruism}

The provision of ex post insurance looks quite similar to redistributive altruism, but two aspects of the data are inconsistent with redistributive altruism. First, religious institutions are not associated with lower inequality of consumption levels, which poses the question why religious institutions would altruistically smooth temporary shocks but not permanent inequality. Ex post social insurance, however, allows the smoothing of temporary and not permanent shocks. Second, altruism fails to explain why only those who participate in pengajian experience alleviation of credit constraints during the crisis and why it is only after increasing pengajian that households experience the greatest alleviation of credit constraints.

\section{Poverty}

My empirical framework finds that an economic shock causes an increase in religious intensity, but by itself, it does not rule out poverty causing religious intensity. In other words, if religious intensity were pegged to income levels instead of income volatility, this could also explain why economic distress stimulates religious intensity. However, religious intensity increases as economic conditions improve after the crisis: pengajian participation rates continue to increase from 61 percent in August 1998 to 71 percent in August 1999 (App. table B2), and the separation between religion and state decreased several years after the crisis (Indonesia elected a Muslim cleric as president in October 1999, and new federal laws mandated that all schools provide Islamic prayer rooms and all children be taught in their respective religion).

A model of social insurance, however, is consistent with an increase in religious intensity even after economic conditions improve. A large shock increases an agent's posterior likelihood of a volatile income distribution. If a large shock stimulates religious intensity, might a small shock, too, and shouldn't religious intensity therefore necessarily correspond to income levels as shocks become arbitrarily small? However, if there are adjustment costs (Chetty 2004) to choosing religious intensity, then small shocks would not affect religious intensity. In fact, dryland hectares, an instrument for a small shock, are not correlated with changes in religious intensity. Finally, other studies do not peg religious 
intensity to income levels: Krueger and Maleckova (2003) do not find that poverty causes terrorism, and DiPasquale and Glaeser (1998) do not find that poverty matters for race riots. Neither is there a relation between pengajian and monthly per capita nonfood expenditures in the cross section in my sample. Because the poor are not more religious, these findings are also inconsistent with wealth-dependent levels of risk aversion.

\section{Inferior Goods}

I argue that economic distress not stimulating other social activities is inconsistent with an opportunity cost view of religion that does not account for religious activity having an economic component not present in other social activities. However, it may also indicate that most social activities are luxury goods. Following this line of argument, if social activities are luxury goods, then to explain why participation in nonreligious social activities declined during the crisis, income effects outweigh substitution effects. This would imply that Koran study is an inferior good, and since the relative price of Islamic schools increased, Islamic schooling is a Giffen good. Very few Giffen goods have been documented, so it would be remarkable if Islamic schooling is a Giffen good like rice and potatoes (Jensen and Miller 2008). Moreover, religious intensity being an inferior good is inconsistent with the general lack of correlation between religious intensity and income as noted in the previous subsection and in Iannaccone (1998).

\section{Labor Bonding}

An alternative explanation for the increase in religious intensity and the concomitant reduction in economic distress is that religious organizations can bond labor: religious organizations may provide a form of work and give money because they can prevent individuals from leaving in a future period. Sending children to Islamic boarding school is one way, but not the only way, to conceptualize this. Whether religions bond labor is similar to the hypothesis that religions purchase religiosity and some are more likely to sell than others, specifically the poor. Two aspects of the data suggest that the bonding of labor is not a good explanation in this case. First, if religious organizations bond labor, then labor supply will be less backward bending where there are more religious institutions. Households in distress should be better able to sell future labor to religious organizations and so do not need to work as hard in the present period. However, the opposite is true: labor supply is more than twice as backward bending in places with a per capita number of worship buildings above the median than below the median, 
although the difference is not statistically significant. Second, if religious organizations bond labor, landless households with few child labor opportunities should be particularly inclined to send their children to Islamic boarding schools. However, landownership is associated with decreases in household size.

\section{Contentment}

Finally, religious intensity may merely increase contentment instead of provide ex post insurance. If so, the decrease in credit constraints may be due to households simply needing less to meet their basic daily needs. Increased contentment may not only reduce consumption but may even reduce the effect of positive income shocks on positive consumption shocks and be consistent with religious institutions reducing the standard deviation of consumption shocks within a village. But increased contentment has a much greater difficulty explaining two other features of the data. First, religious institutions reduce the effect of negative income shocks on negative consumption shocks. Households that increase contentment and lower their consumption needs should have displayed even greater declines in consumption expenditures in response to negative income shocks. Second, it is the households that were less religious before the crisis that become more religious and see the largest smoothing of consumption shocks by religious institutions. If households that were less religious are the ones that increase contentment the most, these would also be the households that should see the largest declines in consumption. Third, households increase religious intensity in response to economic distress but not general distress, as measured by infant deaths. It is therefore difficult to square this evidence with a view that religion is a form of emotional welfare and those who are down on their luck want more welfare.

\section{Conclusion}

In this paper, I test a social insurance model of religious intensity. I demonstrate that economic distress stimulates religious intensity by exploiting the fact that rapid inflation causes relative prices to favor growers of staples, namely rice, and hurt sticky wage earners, particularly government employees, whose salaries are set by federal law. I find that households experiencing a $\$ 1.00$ decline in monthly per capita nonfood expenditures are 2 percentage points more likely to increase Koran study and 1 percentage point more likely to switch a child to Islamic school. These results do not obtain for "placebo instruments," dryland hectares and service occupation. Any counterexplanation for rice growers and government employees displaying changes in religious intensity must 
address why the same changes are not seen for growers of dryland crops and workers in service occupations.

Participation in other social activities, including rotating savings groups, does not increase, and labor supply increases with economic distress. These findings are inconsistent with an opportunity cost view of religious intensity that does not account for social insurance. Instead, using a difference-in-differences strategy, I show that households that increase pengajian during the crisis have less unmet demand for alms and credit for meeting basic daily needs within 4 months. Households that did not participate in pengajian are the most credit constrained and show the least reduction in credit constraints within 4 months. Moreover, the effect of economic distress on religious intensity essentially disappears in places where credit is available. Religious institutions also facilitate consumption smoothing across and within households: they reduce the spread of consumption shocks within a village and mitigate the effect of negative income shocks on consumption shocks within a household. These results are more consistent with a social insurance model in which religion fills a missing market for credit than with alternative theories for religious intensity.

Finally, religious institutions mitigate the effect of negative income shocks mainly for households that were not particularly religious before the crisis. Together with the finding that it is the less religious households that increase religious intensity in response to economic distress and the finding that households increasing in religious intensity show the greatest reduction in credit constraints, my results are consistent with an ex post model of social insurance. I speculate that religion is a risk-sharing mechanism in which people pool their resources and redistribute the pool according to their relative religious intensities. It is as if people choose a proportion of income to put in religious groups and this proportion represents their religious intensity. The pool is then divided according to how much people contribute as a fraction of their income. The model has the empirical implications that those who are hit harder by economic distress will increase their religious intensity and those who are hit less hard will decrease their religious intensity. The effect should be mitigated when other forms of credit are available. Religious institutions facilitate consumption smoothing between and within households. People can receive ex post insurance, meaning that sharing occurs after information is revealed rather than before, by increasing their religious intensity, but strong social sanctions against relative lack of intensity facilitate the stability of ex post insurance by deterring people who receive positive shocks from participating less. Alternative social insurance mechanisms with weak sanctions, such as rotating savings groups, would decline during economic distress. This 
paper presents evidence of the ex post insurance dimension; the social sanctions dimension is presented in other work (Chen 2005, 2007).

Religious intensity is linked more strongly to social violence in regions that are more economically distressed (Chen 2005), and alternative social insurance attenuates the causal effect of economic distress on the link between religious intensity and social violence (Chen 2007). To the extent that governments, international organizations, and nongovernmental organizations are concerned about ideological extremism, in particular because it may lead to religious conflict and violence, these results suggest that increasing their role in social insurance may mitigate fundamentalist tendencies. Indeed, there is evidence that religious intensity is lower in places where there is greater public funding, particularly funding that provides social insurance (Gruber and Hungerman 2005; Hungerman 2005). Countries inordinately dependent on natural resources may be subject to greater fluctuations and may find reducing fundamentalist tendencies to be yet another reason to diversify. Economic shocks have been found to increase conflicts (Miguel, Satyanath, and Sergenti 2004; Miguel 2005), so if globalization increases the risk that individuals face, providing insurance against that risk may be important in preventing ethnic-religious conflicts.

Social scientists increasingly view group identities like ethnicity as social constructs potentially affected by an individual's environment and economic conditions. Religious intensity provides a particularly apt context to study group identity since it is arguably more of a choice than ethnicity. I have provided evidence for a model in which social insurance with punishment is particularly successful in an uncertain environment. This may help explain why some religions and group identities replace others over time. If one models group identities as a form of social insurance (Akerlof and Kranton 2000; Fryer 2003; Chen and Li 2009), then in the long-run competition between social insurance groups, with volatility, religions and ethnic identities with harsher punishment are more stable and successful. As volatility declines, groups or religions with reduced punishment or violence become relatively successful. Violence should be interpreted broadly since it need not be physical. The mere exclusion or harassment of nongroup members (Chen and Sethi 2009), much less the concept of hell common in many religions or discrimination in many ethnicities or nationalities, substitutes for violence that keeps ex post insurance self-sustaining. Given the variation in doctrine, the content of beliefs and the interpretation of religious and legal texts may in fact be subject to economic forces (Greif 1994; Montgomery 1996; Glaeser and Scheinkman 1998; Chen and Lind 2006). 
Appendix A

Data

The empirical analysis draws from the Hundred Villages Survey, collected by the Indonesian Central Statistics Office. The panel data set follows 8,140 households from May 1997 to August 1999, beginning before the crisis and continuing in four waves after the crisis (fig. 1). In the precrisis period, the survey observes 120 randomly selected households in each of 100 communities. A codebook in Bahasa discusses the sampling, saying that the surveyors initially sampled two enumeration areas per village in 1997, with 60 households per enumeration area. In 1998, they wanted to represent more of the village, so in the villages where there were more than two enumeration areas (i.e., areas that they had not yet sampled), they randomly sampled a third enumeration area, randomly dropped 20 households from each of the previous two enumeration areas, and then added a new enumeration area with 40 households. The partial replacement of precrisis households explains why the panel contains 8,140 instead of 12,000 households.

Roughly one-third of the treatment groups left the sample during resampling; however, the attrition rates are similar across the treatment and placebo groups: 28 percent of those owning wetland and 28 percent of those owning dryland left the sample; 34 percent of those not owning any wetland and 39 percent of those not owning any dryland; and 31 percent of government workers, 37 percent of service workers, 32 percent of nongovernment workers, and 32 percent of nonservice workers.

The survey also collects village-level information in the first wave of 1997 and 1998. A more detailed description of the survey questions and variable construction used in the tables is provided below. The survey is in Indonesian and was translated with the help of two translators.

Information on wetland and dryland hectares is taken from the question that asks for the total area that is owned of each of wetland and dryland. Government occupation is taken from the question "Status of main job last week," where the choices are working by ourselves without other's help, working with other's help from temporary worker, working with permanent worker, government staff, public staff, private worker, and family worker. Government and public staff are coded as government worker. In Indonesian, the answer choices for government worker are "Buruh/karyawan pemerintah" and "Buruh/karyawan BUMN/ BUMD." Service occupation is taken from the question "Main job during last week," where the choices are agriculture, mining, industry, electricity, construction, business, transportation, finance, service, and other.

I focus on two outcome measures for changes in religious intensity, $\Delta P_{i j}$. One measure is the response to "In the past 3 months, has your household increased, decreased, stayed the same, or not participated in the study of the Koran (pengajian)?" More precisely, the phrase is "pengajian/kegiatan agarma lainnya," which translates to religious activity; however, translators say that the question would be interpreted by native Indonesians as specifically referring to Koran study; non-Muslims may interpret the question as referring to the equivalent in their respective religion. This question is asked after the crisis and is coded as 
$-1 / 0 /+1$. The other measure is the change in the number of children in the household attending Islamic school. Islamic school attendance is coded as follows. Individuals older than 5 are asked the question "level of highest education that have ever had," which includes the responses elementary, ibtidaiyah (Islamic), secondary school, tsanawiyah (Islamic), junior high/vocational, high school, aliyah (Islamic), diploma I/II, diploma III/bachelor, and diploma IV/ graduate.

Economic distress, $\Delta E_{i j}$, is measured using the per capita monthly nonfood consumption expenditure change from May 1997 to August 1998. Monthly nonfood expenditures are obtained from the question "Total nonfood expense last month." Dividing this number by the household size gives the per capita information. Expenditures are normalized to U.S. dollars to ease interpretation. Exchange rate data come from http:/ /www.oanda.com. The results are qualitatively the same using a CPI index, which comes from http://www.bi.go.id/bank _indonesia_english/main/statistics.

The controls, $\mathbf{X}_{i j}$, include precrisis May 1997 values as follows: household head characteristics: age, years of education (1-8 where $8=$ graduated), gender ( 1 $=$ male, $0=$ female $)$, ever married $(1=$ married, divorced, or widowed; $0=$ not married yet), literate (able to read and write), and follows the media (listened to radio or read newspaper last week); household characteristics: household size, modernity (sum of dummy indicators for the ownership of a stove, radio, television, refrigerator, satellite dish, motorbike, and car), dryland hectares, farming dummy, service worker dummy, and last month's per capita nonfood expenditures; village characteristics: urban dummy, population, area, and number of shops per 1,000 population; geographic characteristics: dummies for flat, steep (the excluded topography dummy is slight angle), beach, forest, valley, and river terrain (the excluded geography dummy is other); and fiscal characteristics: total IDT (a village assistance program) funds received by the average household between 1994 and 1996 and INPRES (implemented during 199697) funding received normalized to dollars per 1,000 population, which divides into funds used for productive economic effort, for buildings and facilities, for offices and institutions, and for human resources.

Participation in other social activities is asked alongside the question on Koran study. Each question follows the same format: "In the past 3 months, has your household increased, decreased, stayed the same, or not participated in . . . ?" is coded as $-1 / 0 /+1$. Same and not participated are coded as 0 . The questions are asked in the following order: family welfare movement (occasional training for women), a program called " 10 helps for housing" (a form of rotating savings group of 10 households in the same neighborhood but whose function is primarily social), a national club designed for common people with the purpose of obtaining useful abilities (considered as a practical nonformal school for adults), burial society, sports, Koran study, and savings clubs (whose meetings are tea parties). Participation in Koran study, savings clubs, 10 helps for housing, and family welfare movement is free. Participation in sports, burial society, and clubs to obtain skills requires fees. According to the village-level survey, 92 percent of villages have sports clubs, 83 percent have clubs for obtaining skills, 96 percent have family welfare movement organizations, 71 percent have Islamic chapels, and 82 percent have mosques. Labor supply information is obtained 
by taking the mean of each household member's "total hours of any work during last week" and computing the change of this mean between pre- and postcrisis periods.

Credit availability is defined as having a bank, microfinance institution (response to the question on "lembaga keu"), or BRI loan product (response to the question on "kupedes") available in the village. Standard deviation of village shock refers to the standard deviation of individual changes in nonfood expenditures over the crisis. A household is considered as needing alms or credit to meet basic daily needs if (1) the head responds that the household does not have basic supplies (response to the question on "mempunyai persediann sembako," which roughly translates to "nine basic needs") for next week or a supply of money (response to the question on "mempunyai persediaan uang"); and so (2) in order to get food (response to the question on "cara memperoleh bhn makanan pk"), they are waiting for a package, (trying to) borrow from someone else, or waiting for someone to give. This information is asked only after the crisis.

Village-level religiosity measures of per capita number of mosques, Islamic chapels, churches, Hindu temples, and Buddhist temples are taken from the 1997 PODES data (Potensial Desa [Village Potential Statistics]), which present 1996 information. The religiosity measures of the per capita number of Islamic boarding schools, religious schools, and seminaries are taken from the 1998 PODES. New religious schools and seminaries are unlikely to have been built during the crisis, so I interpret both pieces of data as precrisis numbers and divide by the 1997 PODES population accordingly (1998 PODES population numbers would be affected by crisis-induced migration).

I use the entire sample of 8,140 households. Appendix table B1 presents some descriptive statistics.

\section{Appendix B}

TABLE B1

Descriptive Statistics

\begin{tabular}{|c|c|c|c|}
\hline \multicolumn{2}{|l|}{ Household Summary Statistics } & \multicolumn{2}{|l|}{ Village Summary Statistics } \\
\hline Percentage own wetland & $31 \%$ & $\begin{array}{l}\text { Standard deviation of village } \\
\text { consumption shock during } \\
\text { crisis (August 1998-May } \\
\text { 1997) }\end{array}$ & $\begin{array}{l}11.42 \\
(1.56)\end{array}$ \\
\hline Percentage own dryland & $66 \%$ & $\begin{array}{l}\text { Standard deviation of village } \\
\text { consumption shock non- } \\
\text { crisis (May } 1999 \text { - Decem- } \\
\text { ber 1998) }\end{array}$ & $\begin{array}{c}9.22 \\
(2.16)\end{array}$ \\
\hline Percentage in farming & $66 \%$ & $\begin{array}{l}\text { Total worship buildings per } \\
1,000 \text { population }\end{array}$ & $\begin{array}{l}3.83 \\
(.28)\end{array}$ \\
\hline Wetland ownership (hectares) & $\begin{array}{l}.17 \\
(.01)\end{array}$ & $\begin{array}{l}\text { Religious schools per } 1,000 \\
\text { population }\end{array}$ & $\begin{array}{l}.12 \\
(.04)\end{array}$ \\
\hline Dryland ownership (hectares) & $\begin{array}{l}.72 \\
(.01)\end{array}$ & $\begin{array}{l}\text { Seminaries per } 1,000 \\
\text { population }\end{array}$ & $\begin{array}{l}.01 \\
(.01)\end{array}$ \\
\hline
\end{tabular}


TABLE B1

(Continued)

\begin{tabular}{lclc}
\hline \hline Household Summary Statistics & \multicolumn{3}{c}{ Village Summary Statistics } \\
\hline $\begin{array}{l}\text { Surname indicates haj } \\
\text { pilgrimage }\end{array}$ & $1.0 \%$ & $\begin{array}{l}\text { \% pengajian participation in } \\
\text { village, August 1998 }\end{array}$ & .61 \\
Number of children attending & .15 & Credit available & $(.03)$ \\
$\quad$ Islamic school & $(.01)$ & & .34 \\
Monthly per capita food ex- & 14.6 & Number of shops per 1,000 & $(.05)$ \\
$\quad$ penditure, May 1997 & $(.1)$ & population & .07 \\
Monthly per capita nonfood & 7.3 & Urban & $(.03)$ \\
$\quad$ expenditure, May 1997 & $(.2)$ & & .20 \\
Household size & 4.16 & 1996-97 INPRES funds in & $(.04)$ \\
& $(.02)$ & \$/1,000 population & .91 \\
Government worker & $6 \%$ & Observations & $(.09)$ \\
Service worker & $10 \%$ & & 99 \\
Religious (attended the haj or & $13 \%$ & & \\
$\quad$ Islamic school before crisis) & & & \\
Observations & 8,140 & & \\
\hline
\end{tabular}

TABLE B2

Crisis Summary Statistics

\begin{tabular}{|c|c|c|c|c|}
\hline & $\begin{array}{c}\text { August } \\
1998\end{array}$ & $\begin{array}{l}\text { December } \\
1998\end{array}$ & $\begin{array}{l}\text { May } \\
1999\end{array}$ & $\begin{array}{c}\text { August } \\
1999\end{array}$ \\
\hline $\begin{array}{l}\text { Monthly per capita nonfood expenditure, } \\
\text { change }\end{array}$ & $\begin{array}{r}-4.7 \\
(.2)\end{array}$ & $\begin{array}{l}1.1 \\
(.2)\end{array}$ & $\begin{array}{c}-.1 \\
(.2)\end{array}$ & $\begin{array}{l}.2 \\
(.2)\end{array}$ \\
\hline Pengajian participation rate $(\%)$ & 61 & Unavailable & 67 & 71 \\
\hline Pengajian increase in last 3 months (\%) & 9 & Unavailable & 7 & 7 \\
\hline Pengajian decrease in last 3 months (\%) & 9 & Unavailable & 10 & 11 \\
\hline $\begin{array}{l}\text { Pengajian participation in villages with } \\
\text { credit available }(\%)\end{array}$ & 63 & Unavailable & 71 & 72 \\
\hline $\begin{array}{l}\text { Pengajian participation in villages without } \\
\text { credit available }(\%)\end{array}$ & 60 & Unavailable & 65 & 71 \\
\hline $\begin{array}{l}\text { Pengajian participation in villages with high } \\
\text { savings }(\%)\end{array}$ & 62 & Unavailable & 70 & 70 \\
\hline $\begin{array}{l}\text { Pengajian participation in villages with low } \\
\text { savings }(\%)\end{array}$ & 60 & Unavailable & 62 & 73 \\
\hline $\begin{array}{l}\text { Pengajian participation in households own- } \\
\text { ing the Koran }(\%)\end{array}$ & 65 & Unavailable & 69 & 73 \\
\hline $\begin{array}{l}\text { Pengajian participation in households own- } \\
\text { ing no Koran }(\%)\end{array}$ & 50 & Unavailable & 62 & 67 \\
\hline
\end{tabular}


TABLE B3

Correlation of Instruments and Precrisis Religious Intensity

\begin{tabular}{|c|c|c|c|c|}
\hline & $\begin{array}{c}\text { Wetland } \\
\text { (Hectares) } \\
\text { (1) }\end{array}$ & $\begin{array}{c}\text { Dryland } \\
\text { (Hectares) } \\
(2)\end{array}$ & $\begin{array}{l}\text { Government } \\
\text { (3) }\end{array}$ & $\begin{array}{l}\text { Service } \\
\quad(4)\end{array}$ \\
\hline & \multicolumn{4}{|c|}{ A. Household Religious Intensity } \\
\hline $\begin{array}{l}\text { Surname indicates a haj } \\
\text { pilgrimage }\end{array}$ & $\begin{array}{l}.001 \\
(.002)\end{array}$ & $\begin{array}{l}.006^{* * *} \\
(.001)\end{array}$ & $\begin{array}{l}-.003 \\
(.007)\end{array}$ & $\begin{array}{l}-.011 * * * \\
(.004)\end{array}$ \\
\hline $\begin{array}{l}\text { Number of children attending Is- } \\
\text { lamic school }\end{array}$ & $\begin{array}{l}.013 \\
(.016)\end{array}$ & $\begin{array}{l}.007 \\
(.005)\end{array}$ & $\begin{aligned}-.007 \\
(.036)\end{aligned}$ & $\begin{array}{c}-.021 \\
(.021)\end{array}$ \\
\hline $\begin{array}{l}\text { Number of adults who attended } \\
\text { Islamic school } \\
\text { Controls } \\
\text { Fixed effects }\end{array}$ & $\begin{array}{c}.021 * * \\
(.010) \\
\text { Yes } \\
\text { Village }\end{array}$ & $\begin{array}{l}.010 * * * \\
(.004) \\
\text { Yes } \\
\text { Village } \\
\end{array}$ & $\begin{array}{c}-.039 \\
(.025) \\
\text { Yes } \\
\text { Village } \\
\end{array}$ & $\begin{array}{c}-.009 \\
(.015) \\
\text { Yes } \\
\text { Village }\end{array}$ \\
\hline Fixed effects & \multicolumn{4}{|c|}{ B. Village Religious Intensity } \\
\hline $\begin{array}{l}\text { Mosques in village per } 1,000 \\
\text { population }\end{array}$ & $\begin{array}{l}.036 \\
(.050)\end{array}$ & $\begin{array}{l}.039 * \\
(.020)\end{array}$ & $\begin{array}{l}.172 * \\
(.095)\end{array}$ & $\begin{array}{l}.028 \\
(.059)\end{array}$ \\
\hline $\begin{array}{l}\text { Islamic chapels per } 1,000 \\
\text { population }\end{array}$ & $\begin{array}{c}-.079 \\
(.145)\end{array}$ & $\begin{array}{c}.033 \\
(.065)\end{array}$ & $\begin{array}{c}-.136 \\
(.278)\end{array}$ & $\begin{array}{c}.112 \\
(.172)\end{array}$ \\
\hline Churches per 1,000 population & $\begin{array}{l}.156 \\
(.110)\end{array}$ & $\begin{aligned}-.009 \\
(.013)\end{aligned}$ & $\begin{array}{l}-.109 \\
(.067)\end{array}$ & $\begin{array}{c}-.032 \\
(.037)\end{array}$ \\
\hline $\begin{array}{l}\text { Hindu temples per } 1,000 \\
\text { population }\end{array}$ & $\begin{array}{l}.012^{*} \\
(.007)\end{array}$ & $\begin{array}{l}.001 \\
(.002)\end{array}$ & $\begin{array}{l}-.004 \\
(.018)\end{array}$ & $\begin{aligned}-.007 \\
(.006)\end{aligned}$ \\
\hline $\begin{array}{l}\text { Buddhist temples per } 1,000 \\
\text { population }\end{array}$ & $\begin{array}{c}-.002 \\
(.001)\end{array}$ & $\begin{array}{l}.001 \\
(.001)\end{array}$ & $\begin{array}{c}-.004 \\
(.006)\end{array}$ & $\begin{array}{l}-.004 \\
(.004)\end{array}$ \\
\hline $\begin{array}{l}\text { Islamic boarding schools per } \\
1,000 \text { population }\end{array}$ & $\begin{array}{l}.002 \\
(.009)\end{array}$ & $\begin{array}{l}.006 \\
(.004)\end{array}$ & $\begin{array}{l}.018 \\
(.020)\end{array}$ & $\begin{array}{l}.004 \\
(.012)\end{array}$ \\
\hline $\begin{array}{l}\text { Religious schools per } 1,000 \\
\text { population }\end{array}$ & $\begin{array}{c}.019 \\
(.024)\end{array}$ & $\begin{array}{c}.002 \\
(.008)\end{array}$ & $\begin{array}{c}-.021 \\
(.031)\end{array}$ & $\begin{array}{l}.034^{* *} \\
(.016)\end{array}$ \\
\hline Seminaries per 1,000 population & $\begin{aligned}-.002 \\
(.002)\end{aligned}$ & $\begin{array}{c}.002 \\
(.002)\end{array}$ & $\begin{array}{l}.004 \\
(.005)\end{array}$ & $\begin{array}{l}.006 \\
(.005)\end{array}$ \\
\hline $\begin{array}{l}\text { Controls } \\
\text { Fixed effects }\end{array}$ & $\begin{array}{c}\text { Yes } \\
\text { Province }\end{array}$ & $\begin{array}{c}\text { Yes } \\
\text { Province }\end{array}$ & $\begin{array}{c}\text { Yes } \\
\text { Province }\end{array}$ & $\begin{array}{c}\text { Yes } \\
\text { Province }\end{array}$ \\
\hline
\end{tabular}

NoTE.-Each coefficient represents a separate OLS regression on an instrument, conditional on controls and fixed effects. Standard errors are in parentheses. All controls are precrisis May 1997 values. Controls in panel A are household head and household characteristics listed below. Controls in panel B are household head, household, village, geographic, and fiscal characteristics listed below. Measures in panel B are collected at the village level, so the corresponding regressions control for village-level clustering and have province fixed effects. Household head characteristics: age, years of education $(8=$ graduated), gender, ever married, literate, and follows media (television or radio). Household characteristics: household size, modernity (index of stove, radio, television, refrigerator, satellite dish, motorbike, and car), farming dummy, service dummy, dryland ownership (hectares), and precrisis per capita nonfood expenditure. Column 2 controls for wetland ownership (hectares) instead of dryland ownership (hectares). Village characteristics: urban, population, size, number of shops, and mean precrisis per capita nonfood expenditures. Geographic characteristics: flat, steep, beach, forest, valley, and river. Fiscal characteristics: 1996-97 INPRES funds per 1,000 population for economic activity, building and facilities, offices and institutions, human resources, and IDT funds.

* Significant at the 10 percent level.

** Significant at the 5 percent level.

*** Significant at the 1 percent level. 
TABLE B4

Reduced-Form Relationship between Instruments and Islamic School AtTENDANCE

\begin{tabular}{|c|c|c|c|c|c|}
\hline & \multicolumn{5}{|c|}{ Islamic School Attendance Change } \\
\hline & (1) & (2) & $(3)$ & (4) & $(5)$ \\
\hline & \multicolumn{5}{|c|}{ A. Main Experiment: August 1998} \\
\hline Wetland hectares & $\begin{array}{r}-.0150 \\
(.0154)\end{array}$ & $\begin{array}{c}-.0259 \\
(.0180)\end{array}$ & & & $\begin{array}{c}-.0262 \\
(.0180)\end{array}$ \\
\hline \multirow[t]{2}{*}{ Government } & & & $\begin{array}{c}.0440 * \\
(.0259) \\
\end{array}$ & $\begin{array}{c}.0451 \\
(.0394) \\
\end{array}$ & $\begin{array}{c}.0459 \\
(.0394) \\
\end{array}$ \\
\hline & \multicolumn{5}{|c|}{ B. Placebo Experiment: August 1998} \\
\hline Dryland hectares & $\begin{array}{c}-.0144 * * * \\
(.00506)\end{array}$ & $\begin{array}{c}-.00324 \\
(.00595)\end{array}$ & & & $\begin{array}{r}-.00324 \\
(.00595)\end{array}$ \\
\hline \multirow[t]{2}{*}{ Service } & & & $\begin{array}{c}.0193 \\
(.0216) \\
\end{array}$ & $\begin{array}{c}.0165 \\
(.0231) \\
\end{array}$ & $\begin{array}{c}.0162 \\
(.0231) \\
\end{array}$ \\
\hline & \multicolumn{5}{|c|}{ C. Postexperiment: May 1999} \\
\hline Wetland hectares & $\begin{array}{l}.0141 \\
(.0103)\end{array}$ & $\begin{array}{l}.00823 \\
(.0128)\end{array}$ & & & $\begin{array}{c}.00833 \\
(.0128)\end{array}$ \\
\hline Government & & & $\begin{array}{r}-.0192 \\
(.0167)\end{array}$ & $\begin{array}{r}-.0133 \\
(.0263)\end{array}$ & $\begin{array}{c}-.0135 \\
(.0263)\end{array}$ \\
\hline Controls & No & Yes & No & Yes & Yes \\
\hline Fixed effects & No & Village & No & Village & Village \\
\hline
\end{tabular}

Note. - Control variables are household head and household characteristics listed in table 2. In the placebo experiment, dryland control is replaced by wetland control. Standard errors are in parentheses. Columns 1-5 display OLS estimates. Islamic school attendance is defined as the number of children households send to Islamic schools. Only households with children attending school before the crisis are included in the sample.

* Significant at the 10 percent level.

** Significant at the 5 percent level.

*** Significant at the 1 percent level.

\section{References}

Abadie, Alberto, and J. Gardeazabal. 2003. "The Economic Costs of Conflict: A Case Study of the Basque Country." A.E.R. 93 (March): 113-32.

AKATIGA. 1999. "Factory Unemployment: Gender Issues and Impacts." Manuscript, Center Soc. Analysis, Internat. Labour Org., AKATIGA Found., Bandung, Indonesia.

Akerlof, George, and Rachel Kranton. 2000. "Economics and Identity." Q.J.E. 115 (August): 715-53.

Alesina, Alberto, Reza Baqir, and William Easterly. 1999. "Public Goods and Ethnic Divisions." Q.J.E. 114 (November): 1243-84.

Azzi, Corry, and Ronald G. Ehrenberg. 1975. "Household Allocation of Time and Church Attendance." J.P.E. 83 (February): 27-56.

Barro, Robert J., and Rachel M. McCleary. 2006. "Religion and Political Economy in an International Panel." J. Scientific Study Religion 45 (June): 149-75.

Berman, Eli. 2000. "Sect, Subsidy, and Sacrifice: An Economist's View of UltraOrthodox Jews." Q.J.E. 115 (August): 905-53.

Berman, Eli, and Ara Stepanyan. 2003. "Fertility and Education in Radical Islamic Sects: Evidence from Asia and Africa.” Manuscript, Dept. Econ., Rice Univ.

Bertrand, Marianne, and Sendhil Mullainathan. 2001. "Do People Mean What 
They Say? Implications for Subjective Survey Data." A.E.R. Papers and Proc. 91 (May): 67-72.

Biddle, Jeff. 1992. "Religious Organizations." In Who Benefits from the Nonprofit Sector? edited by Charles T. Clotfelter. Chicago: Univ. Chicago Press.

Buchanan, James M. 1965. "An Economic Theory of Clubs.” Economica 32 (February): 1-14.

Burr, J. Millard, and Robert O. Collins. 2006. Alms for Jihad: Charity and Terrorism in the Islamic World. Cambridge: Cambridge Univ.

Chen, Daniel L. 2005. "Does Economic Distress Stimulate Religious Fundamentalism?” Manuscript, Dept. Econ., Univ. Chicago.

- 2007. "Islamic Resurgence and Social Violence during the Indonesian Financial Crisis." In Institutions and Norms in Economic Development, edited by Mark Gradstein and Kai A. Konrad, 179-200. Cambridge, MA: MIT Press.

- 2009. "Club Goods and Group Identify: Evidence from Islamic Resurgence during the Indonesian Financial Crisis.” Manuscript, Dept. Econ., Univ. Chicago, http://home.uchicago.edu/ dlc/papers.htm.

Chen, Daniel L., and Jo Lind. 2006. "The Political Economy of Beliefs: Why Fiscal and Social Conservatives (Liberals) Come Hand-in-Hand." Manuscript, Dept. Econ., Univ. Chicago.

Chen, Daniel L., and Jasmin Sethi. 2009. "Does Forbidding Sexual Harassment Exacerbate Gender Inequality?” Manuscript, Law School, Univ. Chicago.

Chen, Yan, and Sherry Xin Li. 2009. "Group Identity and Social Preferences." A.E.R. 99 (March): 431-57.

Chetty, Raj. 2004. "Consumption Commitments, Unemployment Durations, and Local Risk Aversion.” Working Paper no. 10211 (January), NBER, Cambridge, MA.

Dehejia, Rajeev, Thomas DeLeire, and Erzo F. P. Luttmer. 2007. "Insuring Consumption and Happiness through Religious Organizations." J. Public Econ. 91 (April): 259-79.

DiPasquale, Denise, and Edward L. Glaeser. 1998. "The L.A. Riots and the Economics of Urban Unrest." J. Urban Econ. 43 (January): 52-78.

Ellsworth, L. 1989. "Mutual Insurance and Non-market Transactions among Farmers in Burkina Faso." PhD diss., Univ. Wisconsin-Madison.

Fafchamps, Marcel. 2004. Rural Poverty, Risk and Development. Cheltenham, UK: Elgar.

Frankenberg, E., D. Thomas, and K. Beegle. 1999. "The Real Costs of Indonesia's Economic Crisis: Preliminary Findings from the Indonesia Family Life Surveys." Working Paper no. 99-04 (March), Labor and Population Program, RAND, Santa Monica, CA.

Fryer, Roland G. 2003. "An Economic Approach to Cultural Capital.” Manuscript, Univ. Chicago and American Bar Found.

Geertz, Clifford. 1960. The Religion of Java. Glencoe, IL: Free Press.

Glaeser, Edward L., and Bruce I. Sacerdote. 2008. "Education and Religion." J. Human Capital 2 (Summer): 188-215.

Glaeser, Edward L., and José A. Scheinkman. 1998. "Neither a Borrower nor a Lender Be: An Economic Analysis of Interest Restrictions and Usury Laws." J. Law and Econ. 41 (April): 1-36.

Greenwald, A. G., and M. R. Banaji. 1995. "Implicit Social Cognition: Attitudes, Self-Esteem, and Stereotypes.” Psychological Rev. 102 (January): 4-27.

Greif, Avner. 1994. "Cultural Beliefs and the Organization of Society: A Historical and Theoretical Reflection on Collectivist and Individualist Societies." J.P.E. 102 (June): 912-50. 
Gruber, Jonathan. 2004. "Pay or Pray: The Impact of Charitable Subsidies on Religious Participation.” J. Public Econ. 88 (December): 2635-55.

- 2005. "Religious Market Structure, Religious Participation and Outcomes: Is Religion Good for You?" Advances Econ. Analysis and Policy 5 (January): 5 .

Gruber, Jonathan, and Daniel Hungerman. 2005. "Faith-Based Charity and Crowd Out during the Great Depression.” J. Public Econ. 91 (December): 104369.

. 2008. "The Church vs. the Mall: What Happens When Religion Faces Increased Secular Competition?” Q.J.E. 123 (May): 831-62.

Hadiwinata, Bob S. 2003. The Politics of NGOs in Indonesia: Developing Democracy and Managing a Movement. London: Routledge Curzon.

Hartono, Djoko, and D. Ehrmann. 2001. The Indonesian Economic Crisis and Its Impact on Educational Enrolment and Quality. Singapore: Inst. Southeast Asian Studies.

Holloh, Detlev. 2001. "ProFI Microfinance Institutions Study.” Manuscript, Bank Indonesia and German Agency for Technical Cooperation, Denpasar, Indonesia.

Hungerman, Daniel. 2005. "Are Church and States Substitutes? Evidence from the 1996 Welfare Reform.” J. Public Econ. 89 (December): 2245-67.

Iannaccone, Laurence R. 1992. "Sacrifice and Stigma: Reducing Free-Riding in Cults, Communes, and Other Collectives." J.P.E. 100 (April): 271-91.

. 1998. "Introduction to the Economics of Religion." J. Econ. Literature 36 (June): 1465-95.

Jay, Robert R. 1969. Javanese Villagers: Social Relations in Rural Modjokuto. Cambridge, MA: MIT Press.

Jensen, Robert T., and Nolan Miller. 2008. "Giffen Behavior and Subsistence Consumption.” A.E.R. 98 (September): 1553-77.

Kim, Hyung-Jin. 2007. Reformist Muslims in Yogyakarta Village: The Islamic Transformation of Contemporary Socio-religious Life. Canberra: ANU E Press.

Kipp, R. 1993. Dissociated Identities: Ethnicity, Religion, and Class in an Indonesian Society. Ann Arbor: Univ. Michigan Press.

Knowles, James C., Ernesto M. Pernia, and Mary Racelis. 1999. "Social Consequences of the Financial Crisis in Asia: The Deeper Crisis." Manuscript, World Bank, Washington, DC.

Krueger, Alan B., and Jitka Maleckova. 2003. "Education, Poverty, Political Violence and Terrorism: Is There a Causal Connection?" J. Econ. Perspectives 17 (Fall): 119-44.

Landau, David. 1993. Piety and Power: The World of Jewish Fundamentalism. New York: Hill and Wang.

Levinsohn, James, Steven Berry, and Jed Friedman. 2003. "Impacts of the Indonesian Economic Crisis: Price Changes and the Poor." In Managing Currency Crises in Emerging Markets, edited by Michael Dooley and Jeffrey Frankel. Chicago: Univ. Chicago Press (for NBER).

Library of Congress. 1992. Country Study: Indonesia. Washington, DC: Fed. Res. Div., Library of Congress, http://lcweb2.loc.gov/frd/cs/.

Marty, Martin E., and R. Scott Appleby, eds. 1991-95. The Fundamentalism Project. 5 vols. Chicago: Univ. Chicago Press.

Meyer, Bruce, and James Sullivan. 2007. "Further Results on Measuring the WellBeing of the Poor Using Income and Consumption.” Working Paper no. 07.19 (September), Harris School, Univ. Chicago. 
Miguel, Edward. 2005. "Poverty and Witch Killing." Rev. Econ. Studies 72 (October): $1153-72$.

Miguel, Edward, Shanker Satyanath, and Ernest Sergenti. 2004. "Economic Shocks and Civil Conflict: An Instrumental Variables Approach." J.P.E. 112 (August): 725-53.

Montgomery, James D. 1996. "Contemplations on the Economic Approach to Religious Behavior.” A.E.R. Papers and Proc. 86 (May): 443-47.

Moran, Emilio F., ed. 1996. Transforming Societies, Transforming Anthropology. Ann Arbor: Univ. Michigan Press.

Muhaimin, A. G. 2006. The Islamic Traditions of Cirebon: Ibadat and Adat among Javanese Muslims. Canberra: ANU E Press.

Mukherjee, Nilanjana. 1999. Consultations with the Poor in Indonesia: Country Synthesis Report. Washington, DC: Poverty Reduction and Economic Management Network, World Bank.

Nelles, Wayne C. 2003. Comparative Education, Terrorism, and Human Security: From Critical Pedagogy to Peacebuilding? London: Palgrave Macmillan.

Newey, Whitney. 1987. "Efficient Estimation of Limited Dependent Variable Models with Endogenous Explanatory Variables.” J. Econometrics 36 (November): 231-50.

Schiller, Jim. 1996. Developing Jepara: State and Society in New Order Indonesia. Clayton, Vic.: Monash Asia Inst.

Scotchmer, Suzanne. 2002. "Local Public Goods and Clubs." In Handbook of Public Economics, vol. 4, edited by Alan Auerbach and Martin Feldstein. Amsterdam: North-Holland.

Smith, James P., D. Thomas, E. Frankenberg, K. Beegle, and G. Teruel. 2002. "Wages, Employment, and Economic Shocks: Evidence from Indonesia." J. Population Econ. 15 (February): 161-93.

Townsend, Robert M. 1994. "Risk and Insurance in Village India." Econometrica 62 (May): 539-91.

Wagner, Steven. 1999. Summary of Public Opinion Preceding the Parliamentary Elections in Indonesia-1999. Jakarta: Internat. Found. Electoral Systems.

Wolfensohn, James D. 2003. "Fighting Terrorism and Poverty." Op-Ed, http:// www.worldbank.org.cn/English/content/964m6286227.shtml. 